\title{
Persée
}

http://www.persee.fr

\section{On bushbucks without horns : male and female initiation among the Aluund of Southwest Zaïre}

Filip de Boeck

de Boeck Filip, . On bushbucks without horns : male and female initiation among the Aluund of Southwest Zaïre. In: Journal des africanistes. 1991, tome 61 fascicule 1. pp. 37-71.

Voir l'article en ligne

On bushbucks without horns : male and female among the Aluund of Southwest Zaïre. Among the Aluund of southwestern Zaïre, the mwiingoony is open to all circumcised men ; and the chiwiil, to all women who have undergone menarche rites. To initiate men and women into these « sodalities " means transforming them from « bushbucks without horns " (the uninitiated) into knowledgeable initiates so that they acquire a practical awareness of their distinct, yet interdependent, male and female body-selves, of the alternative models of Luunda gender relations, and of the social responsibilities of manhood and womanhood. Light is shed on these creative, transformative initiatory practices ; and rites are analyzed sequentially as a processual bodily action and a generative process of meaning production.

\section{Avertissement}

L'éditeur du site «PERSEE » - le Ministère de la jeunesse, de l'éducation nationale et de la recherche, Direction de l'enseignement supérieur, Sous-direction des bibliothèques et de la documentation - détient la propriété intellectuelle et les droits d'exploitation. A ce titre il est titulaire des droits d'auteur et du droit sui generis du producteur de bases de données sur ce site conformément à la loi n`98-536 du 1er juillet 1998 relative aux bases de données.

Les oeuvres reproduites sur le site «PERSEE » sont protégées par les dispositions générales du Code de la propriété intellectuelle.

Droits et devoirs des utilisateurs

Pour un usage strictement privé, la simple reproduction du contenu de ce site est libre.

Pour un usage scientifique ou pédagogique, à des fins de recherches, d'enseignement ou de communication excluant toute exploitation commerciale, la reproduction et la communication au public du contenu de ce site sont autorisées, sous réserve que celles-ci servent d'illustration, ne soient pas substantielles et ne soient pas expressément limitées (plans ou photographies). La mention Le Ministère de la jeunesse, de l'éducation nationale et de la recherche, Direction de l'enseignement supérieur, Sous-direction des bibliothèques et de la documentation sur chaque reproduction tirée du site est obligatoire ainsi que le nom de la revue et- lorsqu'ils sont indiqués - le nom de l'auteur et la référence du document reproduit.

Toute autre reproduction ou communication au public, intégrale ou substantielle du contenu de ce site, par quelque procédé que ce soit, de l'éditeur original de l'oeuvre, de l'auteur et de ses ayants droit.

La reproduction et l'exploitation des photographies et des plans, y compris à des fins commerciales, doivent être autorisés par l'éditeur du site, Le Ministère de la jeunesse, de l'éducation nationale et de la recherche, Direction de l'enseignement supérieur, Sous-direction des bibliothèques et de la documentation (voir http://www.sup.adc.education.fr/bib/ ). La source et les crédits devront toujours être mentionnés. 


\section{Of bushbucks without horns :}

\section{Male and female initiation among the Aluund of Southwest Zaïre*}

\section{SOCIO-CULTURAL CONTEXT}

There are about 30000 Aluund who live widely dispersed in the Mabeet or "the Valleys " in the administrative zone of Kahemba, an area of $20000 \mathrm{kms}^{2}$, along the Angolan border, and some $1300 \mathrm{~km}$ to the south-east of the capital Kinshasa, in the province of Bandundu. Nzofu, the traditional centre of the Mabeet, is the musuumb or royal village of the southern Kwaango's paramount Luunda chief, Nzav Cheend a Mashiind, a descendant of the mwaant yaav's royal dynasty of the Luunda homeland in Shaba province. The Nzofu territory is more or less delineated by the triangle that is formed by the rivers Koombo, Waamba and Tundwila. Here, the Aluund form the dominant cultural group. Luunda-land is part of what has been called the subsaharan lowfertility area. The Mabeet's poor soil can hardly sustain the population's nutritional demands. The Aluund engage in some agriculture. On cleared spots in the small stretches of rain-forest along the rivers, women lay out manioc gardens. They also gather roots, mushrooms and fruits. The daily manioc diet is enriched by men's hunting and fishing, as well as their tapping of palmwine from the mudidi-palm (Raphia vinifera). Every year, during the dry season, the Aluund live through a period of scarcity, and with the difficulty of access, the Mabeet is cut off from Bandundu's main urban centers. There is no production for commerce, except for the yearly harvesting of caterpillars that are sold as delicatessen to travelling tradesmen.

Descent among the Aluund may be called double unilineal, as a combination of the mother's and father's matriline. This double unilineal descent is asymmetrical. The mother's matriline ( $k u$ umaakw) is the overt line of descent, whereas the father's matriline ( $k u$ utaatukw) is the more submerged one. This gives rise to what Lévi-Strauss (1971:248) has called a dysharmonic structure of patri- or virilocal residence, but with predominant matrilineal descent. The agnatic residential household unit (jiikw or " fireplace ») is headed by a responsible elder or leemb wijiikw, who may be either one's (classificatory) father

\footnotetext{
*. Research was conducted during a period of 19 months from September 1987 till March 1989. I gratefully acknowledge grants made available to me for this research by the "Onderzoeksfonds " of the University of Leuven (director: R. Devisch).
} 
or older brother. Agnatic ties thus define one's direct residential belonging. But one's feeling of belonging is dual. A number of these residential segments make up a lineage or "womb » (vumw), headed by a responsible elder or leemb wivumw, who is normally one of ego's maternal uncles ${ }^{1}$. Lineage membership is thus reckoned primarily in the mother's matriline, through a common, female ancestor, who is identified with the maternal source of life just above the great-grandmother, and who is represented by a senior woman (kanam), in the third ascending generation of the matriline. The dual complementarity of agnatic and uterine principles is also expressed in the Aluund's conceptions on the transmission of life. The basic raw blood-stuff of which life is made, is agnatically passed on by the man through the male seminal fluids, refered to as the "blood of children " (mash ma waan). It is in the female womb that this raw blood-stuff is processed, heated, fed and cooked into vital life-force (mooy) and thus into human beings of both blood, flesh and boney parts. As such, the vital life-flow is located at the mother's side (mooy udi ku umaakw).

On the level of the body politic, the organisation of the political territory or ngaand is marked by a pyramidal structure. The titles are distributed according to a system of perpetual kinship and positional succession. At the apex is situated the paramount chief Mwaant Nzav, whose title is inherited according to strictly patrilineal principles within one main lineage, from father to son. His court is the epicentre of the geographical and political territory or ngaand. Mwaant Nzav unites the function of sovereign ruler and paramount political and territorial chief (mwaant mwiin mangaand) with that or mwiin mavw, or owner of the soil. Trough his person, the society, the human beings, the land and the cosmos are identified as an inseparable unity. In his capacity of mwiin mavw he assumes the regenerative elements in Luunda culture and is responsible for the fertility and fecundity, and the social and biological reproduction of the community as a whole. Through his identification with the founding ancestors at kool, the Luunda heartland, he embodies and makes present the origin of society, and the initial order (wiinshaan$k u l w$ ) which is at the source of Luunda culture. As such, the office and function of the sovereign mwaant is marked by a political and hierarchical function, as well as a more regenerative and mediating one, by both agnatic and uterine, or vertical/linear and more cyclical principles. His authority in the ngaand is represented by fourteen subregional chiefs (ayilool ajim) who followed Nzav during the migration from Shaba, and who each administer the part of the ngaand that was allocated to them by Nzav. These titles, as well as those of less important local lineage and village heads, are inherited according to a matrilineal principle from mother's brother to sister's son.

1. Normally the person responsible for the village's senior (landowning) lineage will also be the one responsible for the village (mwaant $w a u l$ ). A village in the Mabeet does not outnumber 200 inhabitants. The greater part of villages is much smaller and normally numbers between thirty and sixty inhabitants, or between three to six residential units (majiikw) that live as corporate groups and make up a hamlet. 


\section{LUUNDA « FERTILITY » AND THE KNOTTING OF THE CORPOREAL, THE SOCIAL AND THE COSMOLOGICAL FIELDS}

The Aluund hold strong assumptions about the cohesion, maintenance, perpetuation and strenghtening of Luunda society. These assumptions may be encapsulated under the heading " fertility », or, as Bloch $(1982: 212)$ has defined it, " the power of total enablement to total achievement ». I use the overall notion of " fertility », for which there is no equivalent word in uluund, as a working concept, which allows me to include various Luunda notions regarding vital life-force (mooy), strength (usw) or well-being (ngol), under one general heading. Concretely, the proposed notion of fertility includes the gift of children, crops, game (reproductive) health and well-being, or more generally, the ways in which life is regenerated and the vital life-flow (mooy) is transmitted, as well as the ways in which production in the environment is assured or social reproduction is continued and perpetuated. As a working concept, " fertility " thus results from the integration or knotting of the corporeal, social and cosmological fields. For the Aluund, these three fields are intricately tied together, as in a web of « knots » (nkat). The metaphors of tying and of the knot underly much of the Aluund's actions to enhance fertility. For example, the verb that denotes one's " being with strength " or " being in good health » (-kasakan) is formed from the stem - kas, " to tie " or " to bind ». One's health and well-being, i.e. one's « being well tied », not only bounds, defines and sets off one's individual corporeal health but also largely depends on one's being «tied " or knotted into the overall social and cosmological make-up of the Luunda world. For instance, a sorcerer's attack makes one ill because it disrupts this interconnectedness and " ties one with cords " (udi wa kukasil, udi kal ni nkat) into a separated or negative bond that counters and undoes the vital integration between these three fields.

The basic thesis underlying this analysis is that the knotting of the corporeal, social and cosmological fields, from which fertility and general wellbeing spring, is not a pre-established given. Like all societies, Luunda society is liable to tensions and conflictual tendencies. These tensions are embedded in a basic set of oppositions between male and female, or agnatic and uterine principles (with related oppositions as between right and left, day and night, up and down, front and back, sour and sweet, cold and hot, sun and moon and so on). Basically, the Aluund conceive of these contrasting but complementary polarities as being corporeally embodied, or as stemming from corporeal experiences. Following Devisch (1984) and Bourdieu (1980) I view the human body not only as a depository of cultural values but also as creative signifier and producer of meaning. As a basic « knot» (lukat), Luunda corporeal praxis, in its capacity to interlink, conveys its own structural logic or composition in practice to Luunda social reality, as well as to Luunda worldview. As such the basic oppositions that are incorporated on a bodily level are also externalised and transposed. They expand and pervade the totality of Luunda spatiotemporal structuring of the environment, nature and cosmos, as well as the community's social structure. This shows, for example, in the Aluund's way of gender categorization. To summarize, one could characterize Luunda gen- 
der categorization by way of two alternative models (Holy 1965) : a (male political) model of masculine dominance and female subordination on the one hand, and a (female body-linked) model of feminine regenerative powers and male dependence. These two distinct models of Luunda gender relations are partly complementary, but they do also contrast with each other and do not overlap. The male model regards men's authority in the public, economic (control over use-values) and the political domain. The female model privileges the domestic domain (which includes de facto power over strategic agricultural resources) and depicts men as dependent on female nurturing and regenerative powers $^{2}$. The opposite gender models illustrate societal tensions and paradoxes within the Luunda community and conveys a fundamentally asymmetrical interdependence. Within the daily life-scene, food and the culinary process provide many metaphors of growth, birth, life-transmission, regeneration and female fecundity. On the one hand the (re)production of food (through-femaleagricultural and culinary processes) and the regeneration and transmission of life is situated within a private and female domain that aims at physical regeneration. Generation and regeneration of life is seen in relation to corporeal and cyclical processes as between day and night, life and death, or gestation and birth. It is metaphorically linked to processes of cooking and cultivating, which in turn are metaphorically associated with cosmic processes such as the setting sun, the moon, the course of the river-flow downstream and so on. Within the public domain, the female regenerative capacities are subjected to the predominant, male gender model of authority, social control and seniority, which in turn is realized in the elders' authoritative speech (wiingaandj) and gaze, and expressed in metaphors of verticality and linearity such as the sun in zenith, the rain, the crowing cock, the root of the tree, the river's source upstream, the rainbow (nkoongol) or the flash of lightning (nzaj). Men are nevertheless fully aware of the existence of the more diffuse alternative female gender model, which is given shape to in daily practice. To a certain extent, men acknowledge its existence, just as women fully acknowledge the male model, although, in daily life, men are much more dependent on women than women on men. On the socio-political level it leaves men with the problem of accomodating the female model of gender relations within their own model in order to establish, maintain and ascertain its own tenability. In the case of political authority, the joining of female and male principles takes place during the ritual of enthronisation.

\section{MWIINGOONY AND CHIWIIL : THE PERFORMING OF THE DUAL COMPLEMENTARITY}

Mwiingoony and chiwiil are male and female sodalities respectively. They function as initiatory societies, each «possessing » its own esoteric secrets or

2. A common theme in tales by the Aluund and other savannah peoples de Heusch 1972) is the quarrel over the control of food between the sun and the moon. This theme reflects and comments upon the dual complementarity of male and female or agnatic and uterine principles. 
" knots" (nkat) of knowledge. Every circumcised man may become a member of the mwiingoony sodality. In the same way, every woman who has undergone the ufuundeej rituals that mark menarche, may join the chiwiil. Initiation into the two sodalities does normally take place at the death of one of its members. As such, these initiation rituals are closely associated with the munem mourning rituals. During the mourning period crucial parts of the mwiingoony and chiwiil will be performed in front of the mortuary house, and the burial of the deceased member of the sodality is accompanied by specific rituals in relation with the mwiingoony or chiwiil respectively.

To initiate (-kitish : " to cause to wound ») men and women into the mwiingoony and the chiwiil means to transform them from «bushbucks without horns " (nguluung wakaadi nseengw) ${ }^{3}$ or uninitiated persons (antoond), via their status of neophytes (atwaadi), into knowledgeable initiated members of the sodality (atudiaangw and atunyaam-nyaam for men and women respectively). On the corporeal level the rituals aim at the initiating of men and women into an awareness of their male and female body-selves. On a social (and political) level they initiate them into the responsibilities of social adult manhood and womanhood. As such, the rituals stress the dual and contrastive character of male and female body-self, and confirm the alternative models of Luunda gender relations. A true male elder, for example, will have to be initiated into the mwiingoony. Significantly, an uninitiated man may not enter the chiefly courtyard of Nzav. In the same way, the initiation into mwiingoony is a prerogative for the taking on of ritual responsibility in one of the numerous Luunda ritual institutions or mahaamb.

At the same time, the rituals stress the intertwined complementarity and interdependance of opposite principles, necessary for the generating of the society's « fertility " and consequently for its perpetuation. The rituals' " intentionality $"$ is thus twofold, and expresses the basic paradox underlying every initiatory project between the creative and transformative knotting and the reproduction of hierarchic social structures. On the one hand the rituals aim at consolidating the distinctiveness and uniqueness of the male and female body-self. On the other hand, the rituals express how much the perpetuation of society necessarily depends on the complementarity of opposites, which can only result from the interconnection between corporeal, social and cosmological dimensions.

In this paper, I will try to convey how the rituals' twofold intentionality is realized. To achieve this goal, the analysis is on two levels. Firstly, I will briefly investigate the nature of the main " knot " of secret initiatory knowledge in the mwiingoony and chiwiil rituals, as well as the persons that are involved in these secrecy relations. The twofold intentionality of the mwiingoony ans chiwiil ritual is already expressed in the structuring of its body of secret knowledge as " knots ", for a knot embodies a "situation-limite ", as Eliade (1952 : 152) has called it. The knot both attaches and detaches, relates and separates, connects and demarcates or ties up.

3. The bushbuck nguluung (Tragelaphus scriptus ornatus) is also called chisweepw or chibooy. The name is equally used as an abusive word for uncircumcised persons. 
Secondly, I will proceed with a more sequential analysis of ritual as processual bodily action (Devisch 1988, Werbner 1989). I will view ritual as an organic, microcosmic whole, which realises itself in and through its temporal and sequential unfolding. Ritual is sequential corporeal praxis, a creative process of meaning production which processually develops into a myriad network of interlinked meaning. Like therapeutic rituals, institutional rites such as mwiingoony and chiwiil are integrative, self-constitutive performances that attempt to establish, replenish or restore the consonance and vital order between bodyself, social body and cosmological worldview. As such institutional rites share with healing rituals the same basic intentionality of «tying " the participants into a meaningful social and cosmological whole, thereby assuring their health and well-being (kasakan) (Turner 1968 : 198). The ritual enactment, however, is not to be viewed as a mere re-establishing of previously existing orders. The integration is achieved by means of an innovative, creative and transformative production of meaning. By performing the ritual sequences the participants gradually come to embody newly generated meanings. This meaningful production also implies a transgression. As a performative event or lived drama, ritual praxis does not mimetically mirror social reality. Rather, mwiingoony and chiwiil rituals do inventively realise their own intentionality in and through the performance on the initiatory grounds (zeemb or kabaanz for mwiingoony and chiwiil respectively), just like " the telling of a tale invents/interprets itself » (kut ka chishimw kukaluumbunun), as the Aluund say. In order to produce vital order, ritual practice necessarily violates this order by its transgression, and by negating the transgression at the same time (Bourdieu $1980: 367$ ). Ritual unites the oppositions and simultaneously separates what the ritual transgression unites. Its transformative and innovative capability originates from this trespassing and transgressing of boundaries. The zeemb or the kabaanz initiatory ground is the privileged scene on which this ritual drama is performed. It also means that ritual has an immanent efficiency and that the ritual intentionality is embedded within and presupposed by the ritual as self-implicating, illocutionary, performative act (Tambiah 1985).

Ritual practice is essentially idiomorphic. Like a growing crystal it develops according to a certain structure, but just as no two crystals are identical, so every ritual realisation or performance is different. Therefore the Aluund remark that ritual «multiplies its ways » (wavul mpaangw). In spite of this flexibility, I will try to present the basic outline of the ritual sequences ${ }^{4}$.

4. Although both mwiingoony and chiwiil rituals seem to be of undeniable Luunda origin (something Hoover 1978 : 77 seems to doubt), no published account of them exists for the Aluund. An article by Crine-Mavar (1963) describes ritual funeral practices among the Malas, a Luunda sub-group of Shaba. The practices of their funeral acusyaang association bears many resemblances to mwiingoony related mourning and funeral rituals. Mungonge, ngongi, ciwila and iwila rituals have been described for the Luunda-related Pende (de Sousberge 1956), Yaka (Planquaert 1930 : 13-54) and Cokwe (Nange 1981 ; Bastin 1984), all of whom seem to have borrowed these ritual practices from the Aluund. Especially the Pende and Cokwe rituals resemble the overall ritual structure of Luunda mwiingoony and chiwiil. de Heusch's structural analysis (1972) situates the mungonge within the broader context of savannah cultures.

During my sojourn, six mwiingoony rituals were performed in the area. Two of them took place on the occasion of the enthroning of two subregional chiefs. I myself was initiated in one, and participated in and have elaborate data on three of them. As to the chiwiil, this ritual initiation seems to have 


\section{THE STRUCTURING OF INITIATORY KNOWLEDGE AND THE NATURE OF SECRECY}

The basic lukat or « knot » of knowledge in the mwiingoony is conveyed by means of sand drawings to the neophytes on the day that follows the actual rite of passage (see fig. 1). It concerns a tale that focuses on the murder of a mythical mother-figure, Nansoomb :

There was a man, by name of Mukaanz. His wife was called Nansoomb. They lived in the village of Kaampataang, where the rivers meet. They had two children, Mujiing and Kaluumb. Mukaanz was a hunter and also had two dogs, Kawaangal Kangweej and Kangweej Makal. The man left the village to set bird-traps in the tree mwiinful a $n f u l$ (Verbenaceae, Vitex madiensis or V. terruginea. The same plant is also called mwiindal a ndal. In other versions of the tale : chinkuunk : probably Ochthocosmus lemaireanus). To set his traps he had to cross the rivers of Lweembw, Kalwiinsiku (in other versions called Lwik) and Choowal a Mbwaal. The traps caught many birds, with which the whole family was fed. Then a great hunger came to Kaampataang. One day Nansoomb wen begging for food in the villages of Chiaal and Muyeej, the villages of her husband and her mother, upstream from Kaampataang. She crossed the rivers and washed herself in the water of Choowal a Mbwaal (litt. : " the washing of the vagina). Then she passed the traps in which her husband caught birds. She took the bird's feathers and put them in her hair, by way of $n^{2} l^{5}$. With this nsal and a vuund [a ceremonial dress made from the plant mutuungul (Zingiberaceae, Afromamum stipulatum)] she left for the two villages in order to beg for food ${ }^{6}$. When she arrived there, Nansoomb opened her legs to show her genitals (cf. dance in the chiwiil). When the people in the villages saw his they were very content. This is why Nansoomb returned with a lot of food when she went begging. Before arriving home with her husband, she hid the nsal and the vuund in the bush near Kaampataang. The man wondered how it came that his wife returned with so much food. One day, he decided to undertake some begging himself, like his wife, but he returned empty-handed. He wondered : how does it come that my wife always returns with something, but that I return empty-handed ? The man started to worry. Then he had the idea to hide himself along the road that his wife took to go begging. After a while he saw his wife pass by, dressed with the nsal and the vuund. The man appeared and asked his wife who had given her these things. The man got angry. The woman answered him : everything that I wear, the nsal on my head, I made it with the feathers of the birds from your traps. But you aren't smart enough to do so. The man felt a great shame, and took everything away from his wife to wear it himself. Finally he killed his wife with his arrow. $\mathrm{He}$ hid her body in the hole where the red ants make their nest. When the man retur-

4. (suite) lost some of its importance nowadays and is no longer as frequently performed. Thanks to the presence of my wife I was able to witness a major part of one chiwiil ritual and had lenghty conversations with a number of female initiation specialists all over the Mabeet area.

5. The nsal is a kind of hat, consisting of bird's feathers. According to the tale it is Naansoomb who invented this nsal, which is one of the chief's regalia until today. In the mwiingoony's secret language the nsal is called kayaand. As it is said, " women swear chiwiil, men swear kayaand " (ambaand achip chiwiil, amakuny achip kayaand). The kayaand is a swear-word which may only be uttered by initiated men. The swearing of kayaand also indicates that the nsal can never return to the women who originally invented it.

6. The stem of this plant, which is characterised by its very long root, is hollow and measures about one meter. When it dries out, it drops but does not shrivel or lose its leaves. Therefore, it may represent the life of a person who was mown down by death. The plant recurs time and again in contexts of death and mourning. 
ned in the village he gave everything he had taken from his wife to the children. They asked him where their mother was. The man answered that she would come later on. Then the children ate everything that their father had given. A couple of hours later they asked again what had become of their mother. Nowhere was she to be found. The children started to search for their mother and found her body in the red ants' nest. They wondered who had killed and buried her in the ants' nest. From that day on the mwiingoony stayed with the men and does no longer belong to the women.

Other versions of the same corpus of tales describe how Nansoomb also invented the muyiind, stilts that enabled her to go and steal maize on the fields of the villages of Chiaal and Muyeej, without leaving footprints. The chiwiil's basic core of nkat evolves around the same mythical tale. Both the mwiingoony and the chiwiil stress the same fact : initially, the mwiingoony belonged to the women, and the chiwiil to the men. With the arrival of hunger in the land, and with the subsequent killing of Nansoomb and the appropriation of the mwiingoony (the nsal, the ritual dress and the muyiind), the men gave the $n k a t$ of chiwiil to the women by way of compensation. From that moment on, so the tale goes, everybody was content.

The switching of the rituals established the societal order and the nature of relations between the two gender categories. On the one hand, the public (coercive) authority of men is asserted through the killing of Nansoomb. On the other hand, the tale stresses male dependence on female regenerative and nurturing powers, explicitly linked in the act of showing the vagina to collect food. The red ants' nest ( $m$ wizak-zak) also clearly refers to female fecundity.

First, the initiation into mwiingoony and chiwiil is a formal transmission of institutionalised secrets. After the initiation the neophytes of the mwiingoony and chiwiil rituals formally utter a « conditional » curse (-shiing) that will come upon themselves if they convey the nkat to non-initiated people (antoond) and to women (in the case of the mwiingoony) or men (in the case of the chiwiil) ${ }^{7}$. Since the content of the nkat is fairly identical in both the mwiingoony and the chiwiil, the nature of the curse uttered by the neophytes does not so much pertain to the actual content of the secrets as well as to the ways and the contexts in which men and women can communicate about them to one another. Bellman (1984) has observed that it is more important to know the devices that are used to withold and convey knowledge, than to know the information that is concealed. Secrecy is thus a formal matter, a metaphorical communication, rather than a matter of content. The mwiingoony and chiwiil have their own particular devices to communicate and structure, each in their own way, the same basic lukat. These may be specific gestures, a secret and esoteric language, particular sand drawings, a specific use of plants and objects and so on. Most

7. In the evening following upon the final communal meal that closes the ritual (cf further down), a stick of the mukul-tree (Fabaceae, Pterocarpus angolensis) is laid on the sand-drawing (cf fig. 1). In the middle of the stick is made a deep cut, from which oozes the mukul's sticky red, blood-like sap. Some salt is put on this cut, which is compared to the wound of a leprous person (chitat cha kasw, " wound of fire »). By way of curse (-shiingan) all the atwaadi hit the ground with a stick, while calling out wafee, "die ! ". One by one, each of the atwaadi kneels down in front of the mukul, applies his lips to the "wound " and swears an oath " not to speak the nkat of mwiingoony " on the name of his father and mother. The transgression of this oath will cause leprosy to the transgressor. 
of these particular signs and words deal with the corporeal level. For example, the mwiingoony's esoteric language includes almost exclusively words that deal with male and female corporeal parts and related activities. The formalizing of the same basic knowledge allows men and women to communicate their own uniqueness, as " tied up » or set apart from the other. At the same time, the shared substance of these institutionalised secrets connects and ties them together and underlines their complementarity. In the end, male and female knots of knowledge are knotted and tied into one main knot, which constitutes the knowledge concerning the vital order from which individual as well as communal fertility springs.

This brings me to my second point : the relationship between the persons that are involved in relations of secrecy. As Zempléni (1976: 313) has noted, it is the paradox of a secret, that it is only a secret if shared with somebody else : «Propulsé par la tension du refus qui l'a institué, le secret fraie irrésistiblement sa voie vers l'autre à qui ce refus l'a destiné ».

In a relation of secrecy, he therefore distinguishes between " détenteur ", « dépositaire " and « destinataire ». Applied to the mwiingoony, for example, one may call the atudiaangw or initiated men the " détenteurs ", the " owners " of the ritual's secrets. The neophytes (atwaadi) are the "dépositaires ", for the ritual aims at a transmission of the secrets from the initiated men to the atwaadi. To be allowed access to the body of secret knowledge marks a growth towards "becoming a person" (-eekal muntw) and towards wisdom (manaangw), which is essentially an initiation into the process of meaning construction. The growth towards personhood is ritually realised in the initiatory process of access to the coded knowledge, by means of which one's own bodyself and thus also the interconnection between corporeal, social and cosmological dimensions is realised and created in a meaningful way. This also implies the interjoining with other people. The ones for whom the secrets of the mwiingoony are finally and paradoxically destined are the women. They are the true "destinataires" of the nkat, because they are also the ultimate source and owners of the secrets (and vice versa for men in the case of chiwiil). Through the nature of the secret a fundamentally accessary and complementary relationship between initiated men and women comes into existence. The mwiingoony essentially conveys the fact that women are at the origin of the ritual and that men essentially depend on this feminine source of regenerative powers. The ritual itself creatively develops as a metaphor for the broader Luunda political, economical or social structure as well as for interpersonal behaviour. The ritual appropriation (usurpation) by men of female regenerative powers through the murder of Nansoomb), establishes the Aluund's societal order and the male model of gender relations. It is significant that the nsal has become one of the main royal regalia. At the same time, the mwiingoony is the institutionalised recognition of the alternative female gender model of male dependance on female nurturing and regenerative powers. The nsal, political symbol of male public authority (expressed in the right to swear kayaand), has first been invented by the mother-figure Nansoomb. In the same way, the chiwiil fully stresses the distinctiveness of female body-self, while also conveying the message that the nkat of chiwiil are given to women by men, in the form of a small basket 
(kaampaay) containing all the female " secrets ». The basket delineates female knowledge and a woman's social and (re)productive role as cultivator and mother. As such the social and economic dimension of womanhood is defined by men. Significantly, the weaving of baskets is an exclusive male task. At the same time woman fully establishes her own uniqueness in the chiwiil, which develops as the ritual process of corporeal growth towards female cyclical regenerative powers - that escape the male model of social and political control - and thus leads towards the establishing of an alternative feminine model of gender relations. The language of secrecy is the fundamental principle that organises and mediates between these antagonistic but complementary gender roles, and the interdependance of man and woman.

Let me now turn to the actual ritual performance in order to show how the ritual's intentionality concretely realises itself.

\section{THE MWIINGOONY RITUAL}

Sabulul ngaakeey wakubil munaang ? haanzam ! ngaakaam wakubil munaang kachisadi kachiluung, haanzam ! ni chimbuung cha iluung, haanzam ! Chialubil a ngaandw mwiyaand, mwiyaand mudiaay iiny ? Mudiaay kaluung, haanzam ! Mwizak-zak mwakutaangalaany mposw, haanzam ! Ubuleen mposw wachadik mwaan a mpanyeey, haanzam !

Name your grandparent who made the first mwiingoony ritual ? I ask you ! My grandparent who made the first mwiingoony is the day, and the hyena of the night. I ask you !, Downstream where Crocodile, who is there downstream ? I ask you ! It is the underworld. I ask you ! In the red ants' nest, where your ransom will be checked. I ask you ! If you refuse to give a ransom, take a sibling of yours !

\section{Sequence 1. Preparation of the zeemb}

The initial phase starts in the morning. The elder responsible for the preparations for this rite of passage is the initiation master or mwiin mazeemb. Normally he is also the responsible elder of the village's senior lineage. If not, the latter will designate a mwiin mazeemb, together with the other elders, among his agnates. The initiation master will be formally asked by one of the neophytes to perform the ritual. To invest the initiation master into his role the neophyte will give him an arrow (nseew), which constitutes an invitation towards acceptance ${ }^{8}$. This demand is referred to as -funyeesh, " to cause to straighten what was bent down " or " to cause to honour oneself ». By offering the arrow, the novices ask to be "straightened " or initiated into adult manhood. With this arrow the neophytes will be initiated or " killed » like Nansoomb was killed with an arrow by her husband.

Thereupon the mwiin mazeemb can start with the " carving out " (-tootol) of the initiation-ground or zeemb, situated in the bush to the east of the vil-

8. The initial gift from bride-receivers to bride-givers that opens the marriage negotiations is equally called nseew, as is the initial payment of a sufferer to the therapist. 


\begin{tabular}{|c|c|c|c|}
\hline \multicolumn{4}{|c|}{ Index of sequences in the mwiingoony-ritual } \\
\hline sequences & $\begin{array}{l}\text { dramatis } \\
\text { personae }\end{array}$ & place & time \\
\hline $\begin{array}{l}\text { 1. preparation of } \\
\text { the zeemb }\end{array}$ & $\begin{array}{l}\text { - mwiin mazeemb } \\
+ \text { atudiaangw } \\
\text { - villagers } \\
\text { (men/women) + } \\
\text { novices }+ \\
\text { atudiaangw } \\
\text { - kach a mukuund }\end{array}$ & $\begin{array}{l}\text { - zeemb } \\
\text { - choot (public } \\
\text { meeting-place) } \\
\text { - village/zeemb } \\
\text { - zeemb : } \\
\text { kwisak/kwiteemb }\end{array}$ & $\begin{array}{l}\text { - afternoon } \\
\text { - evening } \\
\text { - midnight }\end{array}$ \\
\hline $\begin{array}{l}\text { 2. entrance of } \\
\text { novices on the } \\
\text { zeemb }\end{array}$ & $\begin{array}{l}\text { - mwiin mazeemb } \\
+ \text { novices }+ \\
\text { atudiaangw } \\
\text { - muyiing } \\
\text { - kaleew-leew } \\
\text { - kaminyoongw }\end{array}$ & $\begin{array}{l}\text { - zeemb : } \\
\text { kwisak/kwiteemb }\end{array}$ & - night \\
\hline 3. kukitish & $\begin{array}{l}- \text { avw a nzaamb } \\
- \text { mwiin mazeemb } \\
+ \text { novices }+ \\
\text { atudiaangw }\end{array}$ & - zeemb & - night \\
\hline $\begin{array}{l}\text { 4. coming out : } \\
\text { - rebirth/journey } \\
\text { to the river }\end{array}$ & $\begin{array}{l}\text { - avw a nzaamb } \\
\text { - muyiind } \\
\text { - anlaandimin } \\
\text { - mwiin mazeemb } \\
+ \text { novices }+ \\
\text { atudiaangw }\end{array}$ & $\begin{array}{l}\text { - choot } \\
\text { - towards the } \\
\text { river }\end{array}$ & - dawn \\
\hline $\begin{array}{l}\text { 5. the manioc } \\
\text { mush of } \\
\text { Nalubaand }\end{array}$ & $\begin{array}{l}\text { - nalubaand } \\
\text { - novices + } \\
\text { atudiaangw }\end{array}$ & $\begin{array}{l}\text { - from river to } \\
\text { village, in the } \\
\text { bush }\end{array}$ & - morning \\
\hline $\begin{array}{l}\text { 6. mobbing of } \\
\text { the goat/killing } \\
\text { of the chicken }\end{array}$ & $\begin{array}{l}- \text { mwiin mazeemb } \\
+ \text { novices }+ \\
\text { atudiaangw }\end{array}$ & - village/choot & - morning \\
\hline $\begin{array}{l}\text { - kudjiindjul } \\
\text { - meal } \\
\text { - learning of the } \\
\text { nkat }+ \text { blessing }\end{array}$ & -+ women & $\begin{array}{l}\text { - choot } \\
\text { - zeemb }\end{array}$ & $\begin{array}{l}\text { - afternoon } \\
\text { - afternoon } \\
\text { - evening }\end{array}$ \\
\hline
\end{tabular}


lage. The clearing of the ground takes place in the afternoon. The word zeemb is also used to denote the rear side of the royal court. The court's rear side is situated to the west, or downstream, where the sun disappears into the underworld (kaluung). The word zeemb is etymologically related to the verbs-zeengam, " to bend ", and-zeengish, " to cause to suffer " or " to cause the spirit to be lost ». It is there, at the zeemb, that the neophytes will die and « bend » (-zeengam) for the dead of the zeemb (avw a nzaamb), a role which will be performed by initiated members of the sodality. At the same time, the positioning of the zeemb to the east of the village prefigures the neophytes' rebirth, for it is in the upstream direction of the east, that the source of male fecundity springs and that kool, the primal beginning of Luunda culture and politics in Shaba, is situated. It is also there, in the direction of the rising sun, that " the world awakes " (mwiingaangyeel wacha) and the sun " grows out of the ground " (-vuumbuk). Therefore, a Muluund will always point towards the east with his right hand, the " hand of fatherhood " (chikas chika taatukw), and to the west with the left hand, the " hand of the mother" (chikas chika maakw).

The mwiin mazeemb " carves out » the zeemb by means of two little sticks of mupep and muwudi-wood respectively. The former represents a hoe (lukasw), which is a female instrument, whereas the latter represents a machete (ndjaangw), an instrument with overtly phallic connotations. Luunda proverbs literally refer to the hoe and the machete or axe as female and male. The use of woods confirms this. The name of the mupep (Euphorbiaceae, Hymenocardia acida) refers to kapeep, the animating and life-giving " breath " or wind, related to the vital life-force mooy, which is predominantly situated in the matriline : mooy udi $k u$ umaakw, "the vital life-flow is with motherhood ", for it is there that mooy is animated through the "blowing " or " kindling of the fire " (-peep). The muwudi-tree (Apocynaceae, Dyplorhynchus condylocarpon or D. angolensis), on the other hand, always occurs in outspoken masculine contexts. Its white, sticky latex is reminiscent of male seminal fluids and is used to stick feathers on arrows, symbols of male virile sexual prowess. With the former in the left, and the latter in the right hand, the mwiin mazeemb makes a small hole in the earth to mark the entrance or the "doorway " to the initiatory grounds (chiiy chi zeemb). Every village has its particular ways of « opening » (-patulul) the doorway. In the three rituals that I witnessed the doorway was marked by a stick of the musehe-tree (Vangueriopsis lanciflora) on the left, and a kapwiip (Swartzia Madagascariensis) on the right. These two tress have marked purifying capacities. The mupep or hoe is tied to the musehe and the muwudi or axe to the kapwiip. In the middle of the doorway the " hoe " and the " machete " hook into one another, thus barring the entrance to non-initiated people. Only atudiaang $w$ will know the specific way to unhook the two sticks and the accompanying ritual formulae. After the marking of the doorway, the initiation master plants a long pole (luseel lwi zeemb) from the wood mupool (also called mukal), a tall slim tree with white wood (Liliaceae, Smilax Kraussiana) in the middle of the zeemb. I speculate that the pole (luseel) represents the mwiinful a nful tree where the hunter Mukaanz installed his traps. There is no doubt that the luseel is a clearly masculine, phallic element, referring to 
the " uprightness» (nteendeend) and erectness that characterizes a true elder9. Significantly, the mupool-tree figures in the praise-name of paramount chief Nzav. The word pool, which means " courtyard ", or " home " is also etymologically related to kool, the Luunda heart-land. Moreover, the pole (luseel) is the central vertical pole which sustains the roof of the house. The Aluund use to compare the family elder to such a pole, for he is responsible for the members of the household, and supports them like the luseel pole supports the roof. Here, the luseel or central pole turns the zeemb into the house of death, or the underworld (kaluung), where the deceased avw a nzaamb (from - $f w$ : " to die ") will initiate the atwaadi. The context of death is reinforced by the plants mutuungul and mukuundikil or mukuundingil (Vitaceae, Cissus Rubiginosa), attached in the top of the luseel or pole ${ }^{10}$. The initiation ground is thus conceived of as a house, which is a feminine space. The house (chikuumbw) is the place where the hearth (jiikw) and the fire (kasw) is situated, and as such it is equally likened to a womb. For the Aluund, entering a house mirrors, in a certain sense, the act of penetration or " entering a woman's belly " (-iingil mwivumw dia mubaand). An impotent man will, for example, be called kachifw muunz, " he who dies inside the house ». The planting of the luseel is a symbolic impregnation of this female domain, mirrored in the intertwining of the muwudi and the mupep. In the song of the kach a mukuund (cf later on) the neophytes are compared to water in a gourd, which is again a metaphor for the initiation ground as womb.

Through their nightly meeting with death, the neophytes are at the same time regenerated into life. The representation of the underworld as a gourd/womb to which the dead/foetus returns is a popular image in the songs of the munem mourning cycle. The zeemb as house, gourd and womb, associated with the downward movement of the sun, with the west, " the place where one is made white " (kuchitookil), with kaluung and the night, is also the space of gestation, where life is cooked and regenerated into rebirth. Cosmologically, the red glow of the setting sun which disappears in the west is spoken of by the Aluund as the fire by which the dead warm themselves (kasw ka anvuumb). On a corporeal level, the male sperm, referred to as the «blood » or the " water of childhood " (mash ma waan, meem ma waan), "leaves the penis and enters the vagina to warm itself at the fire » in the womb (mwaan wadiook mu kulutw, waay mwi mbwaal ni koot kasw). Similarly, the atwaadi will warm themselves during the night at the fire on the zeemb. In the underworld the red glow of

9. Significantly, Gilges (1955) notes that both the mwiinful a nful and the chinkuunk trees are used in the treatment of male genitalia among the Luunda-related Balovale peoples of former northern Rhodesia.

10. Like the mutuungul, the mukuundingil plant is part of the mourning dress in the mourning rituals at the death of a member of the mwiingoony or chiwiil. As such it is refered to as masees or masas ma mufw, "the mourning dress of the dead person ". Only initiated people will wear these plants. The word masas, which literally means "dust ", also refers to a transitional period. For example, a woman who has been attained by a spiritual agency (haamb) during pregnancy will be treated in a seclusion hut (maseeku). The period of a woman's seclusion in the maseeku will be refered to as a period of masas. Similarly, the period of mourning is equally called masas, as is the initiates' mourning dress. 
the sun is transformed into the white of the moon, just like the dead people are turned into white ancestors. At the same time white is also the colour of life-giving forces, as represented, for example, in kaolin (lupeemb). A living, healthy person will therefore be spoken of as muntw wa mpeemb, a «man of whiteness " or a "man of life ". As the red of the sun is turned into white in the underworld, so the male raw, red blood-stuff is cooked and heated in the womb inco "white » life. Life-transmission is thus conceived of as a feminine, cyclical process or "saving circularity », to borrow the words of Fernandez (1982:9), involving both the passage through death and regeneration. The red ants' nest, in which Nansoomb is buried, and which is another metaphor for the zeemb, explicitly relates death and feminine fecundity (ngooj) or the " capacity to regenerate" (nshiw).

After the planting of the luseel, the zeemb is then divided into two halves by means of a linear or circular fence, made from palm-leaves. The part $k w i$ sak (where the luseel stands) is the "public " part of the zeemb, where the novices will be gathered. $K u$ muteemb is the most secret part to the west of the zeemb. On the teemb hide the $a v w$ a nzaamb, and no kaadi is allowed to enter there, nor indeed would dare to. After the clearing of the zeemb and the preparation of the herbal medicine " to ease the pain " (mijimu) that is inflicted upon the neophytes during the initiation, an initiated member of the sodality (kadiaangw) appears in the village, in full ritual dress (masas). This dress consists of a skirt of the mutuungul-plant, a hide of nshiimb (Genetta tigrina or G. genetta) ${ }^{11}$, and with bird-feathers stuck in the hair. The kadiaangw will only talk to his ayiwaaj or parents-in-law, and flee from his cross-cousins. This behaviour reverses the normal joking relationship between cross-cousins, as well as the relation of distance and respect deemed proper in the $u$ waaj relationship between allies. This behavioural reversal on the social level marks the cosmological reversal from day (sun) into night (night), and the corporeal reversal from life into death, which characterises the world of the zeemb. On the appearance of the kadiaangw, the atwaadi set out to gather the firewood that will be used during the night kwisak.

At sunset, all the villagers gather on the choot, the village's male public meeting place, to perform songs and dances from the munem, chiwiil and mwiingoony song-cycles. The neophytes are given a mutuungul-plant, which marks their imminent death, as well as a raffia-ring which they will wear on the right hand's little finger all through the night. The ring again represents the neophytes' " being tied to " death, and also prefigures their rebirth in the morning, for it includes an allusion to the vaginal opening and sexual intercourse. The sticking of the finger in the ring mirrors a common Luunda gesture which denotes coition, and in which the index finger of the right hand is made to enter the ring, formed by the thumb and index-finger of the left hand.

Each of the neophytes will present a gourd of palm-wine to the initiation master. Thereupon, every novice chooses a personal guardian (chikolkol) to assist him during the night. These guardians are initiated elders. The relation-

11. The nshiimb is a nocturnal animal, reputed to grab chicken. Like the nshiimb, the atudiaangw will "grab» the neophytes to « kill » them during the night. 
ship between the guardian and his novice is modelled upon the protective relationship between a mother and her child. In the same way, it is the guardian who acts as gestatory for the novice during the nocturnal stay on the zeemb. The connotation is further strenghtened by the corporeal posture of the novice at the moment of the actual initiation, during which he will crouch between the guardian's legs, as if the latter were giving birth to him. The same might be said about the mwiin mazeemb. The vital relationship between the maternal uncle (mantw) and his sister's children, which forms the backbone of the continuation of the lineage, serves as a model for the relationship between the mwiin mazeemb and the novices. Like a maternal uncle is called the " mother without breasts " (maakw wakaadi mayeel) and is the responsible elder (leemb) of the lineage or "womb " (vumw) in which the vital life-flow is passed on, so the mwiin mazeemb acts as the leemb of the novices, in the same way that he acts as a leemb for all the villagers, in his capacity of village headman (mwaant wa $u l$ ). In this mediating, maternal capacity it is he who is responsible for the transmission of life and the rebirth of the atwaadi.

Finally, the initiation master calls out a warning to possible sorcerers who might attempt to lengthen the duration of the night, and therefore the sufferings and the annulment of the neophytes, by means of sorcery (ulaj).

Around midnight the initiation master orders the fire to be lit on the zeemb. One of the guardians takes a burning stick from the fire on the choot and runs off with it to the zeemb. The lighting of the fire again evokes the process of life-giving impregnation. The fire is the locus of the female universe in the household space. The lighting and kindling of the fire is an equally female activity (cf.-peep above) although the fuel of the fire consists of masculine materials. Significantly, " to strike the fire-stone " is spoken of as "striking of the sword of fire » (-bul mpak ya kasw). Mpak or " sword » also evokes the chiefly sword, called mpak ya mwiil. Mwiil is an archaic uluund word for " elephant's trunk ». Like the axe, the sword and the elephant's trunk have overtly phallic connotations and refer to the male genitalia. Like firewood feeds the fire, so the male penis is the fuel or the wood that enables the fire to burn in the womb. Therefore, the penis is often compared to a tree, and sexual intercourse is referred to as " the pushing of the tree " (-bachik mutoond), which denotes the movement of the penis because of the woman's "kindling " or moving with her pelvis (-yeket, -meeng). The penis thus provides the fuel of the uterine fire, which is kindled by the woman's movements. By lighting the fire, the seminal fluids are processed into a human being. In the same way the lighting of the fire on the zeemb by one of the guardians marks the novices' conception and gestation in the "womb ».

Firstly, the initiation master (mwiin mazeemb) adresses the novices (atwaadi) and formally asks them whether they have been circumcised. Upon the affirmative answer the guardians lead the atwaadi to the zeemb initiatory grounds. From this moment women and children must remain inside their houses until sunrise. When everybody has retreated, a kadiaangw called kach a mukuund, " the one who announces the path (to death) " walks through the village from west to east and halts kwisak, where the novices are gathered. The kach $a$ mukuund (equally called shamakoonk kayaand) formally opens the initiation 
ritual. He walks through the village with a feather hat (nsal) on his head and is accompanied by a second kadiaang $w$ who holds two nzeenzw or rattles, that are made from the fruits of the mwiinzeenz-tree (Rubiaceae, Acacia polyacantha or A. campylacantha). According to a tale, the fruits were first discovered by a hunter in the hole of the rat kuunz. The excrement of this rat is used in the ufuundeej menarche rituals as markers of female fecundity, because the kuunz rat is known to produce several young at a birth and at short intervals of time. Here the fruits are said to represent Nansoomb's children Mujiing and Kaluumb. The kach a mukuund thus not only leads the path to death but also to female fecundity and regenerating powers. During his cosmogonic journey through the village from west to east, the kach a mukuund sings out a lenghty song full of esoteric references concerning the origin of the mwiingoony. Upon nearing the zeemb the kach a mukuund does directly address the atwaadi, who are gathered around the fire :

The path of the atwaadi is not indicated by trampled grass (nobody went there before, for it is the way that leads to the underworld). Where did you all go ? I have called for so long, I am tired, where did you go ? You died. Like water in a gourd (just like the water cannot escape from the gourd, or a baby from the mother's womb, so the atwaadi cannot escape their initiation). There is a fire in the middle. Where will we go ? There where the fire is, are many people. Why did they come here in this immense night?

The kach a mukuund mimicks the atwaadi's answer : "We came in search of munaang (esoteric word for the mwiingoony), the munaang a nselel (the mwiingoony of the grandparents : the sun and the moon, or Mukaanz and Nansoomb). ", and he continues : "Akaa (cry of despair), if you are dead, you died already. Where did they come from for me to initiate (-kistish) them ? " The mwiin mazeemb answers : "They came from their villages".

\section{Sequence 2. The appearance of muyiind, kaleew-leew and kaminyoongw}

- Muyiind : The arrival of the kach a mukuund on the zeemb marks the beginning of the initiation and the gradual revealing of the nkat.

The first figure to make his entrance on the stage of the zeemb is the stiltwalker muyiing (sometimes also called mboong), while the drums start beating the rhythm of the mwiingoony, and the atudiaangw cry out : ngoongu weez, weez ushiiw, "the monstrous comes, orphanhood comes ". Some tales of the mwiingoony complex relate how muyiind represents death ${ }^{12}$, the unknowable, and the monstrous (ngoongu), because "with mwiingoony comes fear " $(k u$ mwiingoony weez woom). The muyiind makes tangibly present the reversed and therefore atrocious order of the underworld, acted out by the fact that it walks through the air. "Orphanhood " refers to the muyiind as a representation of the murdered Nansoomb and the loneliness felt by Mujiing and Kaluumb, the children of Nansoomb. In front of the terrifying and the un-

12. Therefore, muyiind will always appear during the mourning period for a member of the sodality. It is said that muyiind thus speaks for the deceased. Normally, two muyiind appear together on the zeemb. 
known, the atwaadi are without relatives to support them, just like orphans. To appease the monstrous, also referred to as chidiaany, " that which eats people », the mwiin mazeemb offers a chicken, formerly presented to him by the atwaadi, to the muyiind, who thereafter retreats.

- Kaleew-leew : Subsequently, one or two of the avw a nzaamb, whose naked bodies are wrapped in the white bark of the mudidi-palm, thereby giving them the white appearance of the dead, appear from behind the screen that divides the $s a k$, the public part of the initiation-grounds, from muteemb, the most secret part where the novices are not allowed to come. Very quickly, they run around the sak with their arms spread wide open, prefiguring the attack of the dead on the neophytes (cf further on).

- Kaminyoongw : The third lukat to appear are the avw a nzaamb, the spirits of the dead, who will perform a first dance in front of the neophytes. A feather of the chicken that was presented to the stilt-walker muyiind is burned by one of the avw a nzaamb. The smell of the burned feather is called kaminyoongw. It is the " bad smell of the deceased " (ndjiimb dia nvuumb; munyoong : strong smell), which announces the arrival of the $a v w$ a nzaamb ${ }^{13}$.

The whole second sequence is marked by its strongly disruptive character. The descent into the underworld implies a "disruption of the vital order" (-alumun nshiku) and a mixture of vital boundaries (as between life and death, night and day, male and female) that instills horror and is considered to be evil. The stilt-walker, kaleew-leew and kaminyoongw instill the atwaadi with fear and provoke « revulsion ». Because of their transgressive character, these " wonders » (yipupw) are also " evil things » (yoom ya nzaanj). The quality of nzaanj is also applied by the Aluund to faeces, putrefied flesh, fermentation, decay, or to substances with a strong smell such as menstrual blood. Significantly, a dispute between members of a village may be referred to as nvuund (-vuund : to putrefy) for it disrupts the community's vital order (cf the name of Nansoomb's ritual dress). The smell of the kaminyoongw evokes putrefaction and thus underlines the ritual's transgressive and monstrous character, which links it to the sorcerer's nocturnal counter-world (see also note 17). It is no coincidence that the female menstrual seclusion hut at the edge of the village is referred to as muteemb, like the most hidden and secret place at the edge of the zeemb where the $a v w$ a nzaamb hide. The menstrual blood flow (-teem$b u k$ ) inverses the life-giving ejaculation and depositing of male childbearing blood in the female womb. Therefore the menstrual blood-flow provokes a polluting inversion of corporeal boundaries. Yet, it is a necessary sequence in the

13. Other masks, such as kataangal waang, chiyeey, chizemazem, dipaang and others may appear during the night. Owing to shortage of space I cannot provide a fully detailed account of the sequential process in all its richness. I refer to a forthcoming publication which will deal with mwiingoony and chiwiil rituals in more detail.

The stilt-walker's body is painted with specific drawings (in kaolin and red earth (mukuundju) that represent specific nkat. The same goes for some of the atudiaangw. The latter, as well as the kach a mukuund also wear ankle-bands to which are attached the so-called ambaansh, consisting of the fruits (called mayoong or makwaaku in the mwiingoony's secret language) of the forest liana mwiinzoomb. Five different ways of wearing these ankle-bands are known, each of which corresponds to a particular drawing on the body of the kadiaang $w$ who wears it. If a kadiaang $w$ wears a particular drawing without knowing what it refers, he will have to pay a ransom to the initiation-master. 
regenerative process. In the same way the disruptive descent into the underworld, represented by the appearing dead, and the transgression of the established order of the licit is necessary for the production and invigoration of the societal vital order. The teemb, as most secret place of the initiatory ground, is the locus of the violating and disruptive forces, that - paradoxically enough - enable to negate disruption and to innovatingly transform it into an harmonious interjoining between corporeal, social and cosmological fields. The disruption of the vital order is most directly situated on a corporeal level. The attack of the avw a nzaamb on the bodies of the novices violates and entrenches upon their corporeal boundaries and makes their blood flow like that of menstruating women. The transgressive descent into the underworld and the submission to the physical disintegration will transform the novices from « bushbucks without horns " into distinct adult men. Just like a woman menstruates or "walks to the edge " (mweendil kuuns), as the Aluund express it, to reemerge with a fecund maternal body which becomes the centre of lifetransmission, so the atwaadi have to be initiated or " wounded » (-kit) by disruptive and inversive forces " at the edge " to emerge as true male members at the centre of the community.

\section{Sequence 3. Kukitish : the dying in the womb}

After kaminyoongw has retreated, the avw a nzaamb appear for their first attack on the neophytes, while the other atudiaangw start singing mbaansh kayaand kayaand twiteembaany, "kayaand, let us make the blood flow ». By attacking the atwaadi they also manifest their rage for being dead against the living. The naked atwaadi are lined up and lie crouched between the legs of their guardians, who firmly hold them in order to prevent from fleeing the attack of the $a v w a$ nzaamb, while at the same time trying to protect their novice or kaadi as much as possible from the dead's painful attack. The latter wound the atwaadi's behinds by means of animal claws, needles, small knives and so on. Before every outbreak, they are called to the public part of the initiation grounds ( $s a k$ ) by the beat of the drums, directed by the mwiin mazeemb. When the drums fall silent, the $a v w$ a nzaamb retreat in the teemb, after performing a dance together with the initiation master and the other atudiaangw. This dance is referred to as kutaamb. The verb -taamb denotes the women's collective fishing method. Women catch fish by progressing in a line in upstream direction while holding a large halved gourd, called chitaay, in the water to bail out fish. Like the women catch fish, so the avw a nzaamb do catch the neophytes. Luunda proverbs refer to the womb as a chitaay. The fish in the chitaay is like male semen in the womb. The danced performance, which imitates the women's fishing movements, again refers to the same basic womb/gourd metaphor and the cycle of regeneration. The neophytes, " the children of pain » (aan a mijimu) will be reborn only by entering death, " killed» (-jip) by the avw a nzaamb. All the initiated men on the zeemb therefore wear their loin-cloth in mourningfashion, tied between the legs (mwiinkaank), like a baby's. The attacks of the dead persist until sunrise. 


\section{Sequence 4. Coming out : rebirth and the journey to the river}

When the cocks start to crow (pa mandeemb) the atwaadi are led to the choot where the stilt-walker makes another appearance. The avw a nzaamb and the atwaadi dance the munem, mwiingoony and musaang $w$ dances, lined up in two rows, facing each other. The musaangw - dance is a sword - dance, normally only performed by elders at the royal court or at important events such as the enthroning of a title-holder. The dancing of the musaangw (-funy) is the corporeal enacting of an elder's pride, erectness, uprightness (nteendeend), strength (manany) and virility (maandaand). The same verb -funy denotes a chief's majestic stride with his fly whisk. The verb's causative form, -funyeesh, " to cause to lift up what was ben down " was referred to above. It marks for the first time the neophytes' growth towards full adult manhood.

Alfter this dance, the neophytes start their journey (hakatuump) to the source. On the path that leads to the source, they pass one by one under the spread legs of muyiind, thereby enacting the process of parturition and thus of their rebirth. Each of the novices will give a ransom (luposw) to the stiltwalker. Their birth is further marked by the fact that they subsequently have " to step over " the sleeping $a v w$ a nzaamb, without touching themp. The latter, now referred to as anlaandimin, are lying across the path ${ }^{14}$. The act of stepping over is the sign of the novices' domination over death. The actual rebirth takes place at the source (musul), where the neophytes take a purifying bath and get finally rid of the raffia-ring, which tied them to death.

\section{Sequence 5. The manioc mush of Nalubaand}

Upon returning to the village the whole group, led by the guardians, goes to eat "the manioc-mush of Nalubaand " (luku lwa Nalubaand). The name Nalubaand literally means "the mother of womanhood", and as such refers to Nansoomb, « she who generates (life) » (nvaaj). This ritual takes place near the zeemb, at the hole of a njiimbw or aardvark (Orycteporus afer), a nocturnal animal which feeds on ants and termites. Because of its nocturnal and subterranean existence the aardvark is considered by the Aluund to be a representative of the underworld. "The path of the aardvark » (mukuund a njiimbw) is the path which leads to kaluung (see also Rodrigues de Areia 1985 : 301). Here its hole equally represents the nest of ants (mwizak-zak) where Nansoomb's body was buried and where the mythical figure of Nalubaand has her dwellings. The neophytes gather around the entrance of the aardvark's hole. In the hole, hidden by palm leaves, sits the initiation master. A small fire is lighted in the hole, the smoke of which spirals out, while the initiation master imitates the ghostly voice of Nalubaand: "Nkoloonv inv nkoloonv taant a mitay. Kasanyeeng kasanyeeng ka mukuund a njiimbw ${ }^{15}$. »

14. I am not sure about the meaning of the word nlaandmin. Probably, it stems from the verb -laand, " to buy ". If the novices touch the anlaandmin while stepping over them, they will have to present a small gift to them. As such they "buy " their passage from death to life.

15. The exact meaning of these phrases is not clear to me. Nkoloonv is the name of a bird, the pied hornbill (Tockus fasciatus), which was captured by Mukaanz in his bird-trap. The two phrases reoccur in a tale concerning the stilt-walker, who is called nkoloonv taant a mitay. A second person in the 
From the hole a ball of ritually prepared manioc mush (prepared by the initiation master's senior wife) is raised on top of a stick. Each of the atwaadi will squat down near the hole " to eat » from the manioc-mush. Every kaadi sticks his right hand into the hole, where, instead of getting hold of the mush, it is bitten ny Nalubaand ${ }^{16}$. It is said that by biting the atwaadi, Nalubaand manifests her rage against all those who have been initiated in the mwiingoony, since it originally belonged to the women. As such the biting of the novices' hand could possibly be taken to mark the rupture with the maternal universe and the painful growth into antonomous adult men. Upon leaving the hole the atwaadi are dressed by the guardians in full ritual mourning dress of mutuungul and mukuundikil plants (cf the vuund dress of Nansoomb and the masas outfit of the atudiaangw). To show their mourning over the death of Nansoomb their faces are made black with charcoal. Singing mourning-songs, they return to the men's public meeting place (choot). There the atudiaangw who performed the part of the $a v w$ a nzaamb start dancing in a widening circle around the drummers, while they hold one or more leaves of the tree muwudi in their mouth. The leaves indicate the number of times they participated in an initiation night, and are stuck together on a small stick and deposited in front of the drummers. Then, they start dancing with the atwaadi, in two parallel rows, while the village's women come out of the houses and start dancing in a second circle around the neophytes. The dance ends when the line of the atudiaangw merges with that of the atwaadi.

\section{Sequence 6. The clubbing of the billy-goat and the killing of the chicken}

Subsequently the neophytes start to hunt down those men who fled from the village the previous day because they feared to be initiated. In a violent and chaotic atmosphere, the neophytes revenge themselves on these men, by clubbing to death the first billy-goat they can lay their hands on. The men who fled will have to make good this loss to the owner of the goat. The goat itself is dragged in triumph to the zeemb.

Immediately afterwards the mwiin mazeemb brings a white chicken to the choot. The atwaadi line up in two parallel rows. The initiation master then lets the chicken run in between them. The kaadi who invited the initiation master to perform the mwiingoony by giving him an arrow, will then shoot (-chaant) the chicken with the same arrow. Thereupon all the other atwaadi start clubbing the chicken to death. The chicken is plucked by the atudiaangw at the luseel-pole on the zeemb. Each of the atwaadi receives a feather (moon ma $n z o o l)$ which he will stick in the hair.

The clubbing of the billy-goat and the killing of the chicken is the enacting of the achievement of the male virile body-self and public, coercive autho-

15. (suite) tale is muyeej, " the one who is ill ", called "Kasanyeeng of the path of the aardvark ". In the tale Muyeej dies and is represented by Muyiind. Clearly, the tale alludes to the death of Nansoomb. 16. To know whether one has really been initiated in the mwiingoony it is often asked " at what time did one eat the manioc mush of Nalubaand ? " Those who have been initiated know they have to make a specific gesture with the thumb and the middle finger of the right hand by way of answer. 
rity. To the Aluund the chicken, and especially the egg-laying chicken (nzool wabutimin) is a powerful metaphor for female, regenerative capacities and motherhood. In the same way as the mother-hen hatches out (-teet) the egg, so the novices have been hatched out through their stay on the zeemb. Both the zeemb and the womb have an ovum-like quality in that they shelter the novices or the foetus. At the same time the verb -teet evokes the idea of parturition, and is equally used in the sense of " to cut ", " to chop ", " to slice ". The verb also denotes the cutting of the umbilical cord. The killing of the white chicken mirrors the killing of Nansoomb and the rupture with the maternal universe. At the same time the killing refers to the mother' loss of life because of giving birth. A fertile woman is said to " bleed children » (nvaaj witeemb nawaan). Giving birth thus means to lose blood, which implies a loss of vital life-force. Thirdly, the killing implies the masculine appropriation of female life-transmitting and nurturing capacities (which is further evoked by the chicken's whiteness). Rebirth and victory over death is thus also symbolically conceived of as a victory over female sexuality (see Bloch \& Parry $1982: 22$ ). The act of shooting is also a strong metaphor of male virile sexuality. By putting the chicken's feathers in their hair, the neophytes fully become initiated men and symbolically acquire the authoritative status of the elder. After the killing of the chicken, the testicles of the billy-goat are displayed on a stick (muhitw) and carried around the village by the atwaadi. At every house, the women will hand over a small gift (some manioc roots or peanuts) to the novices, while the latter sing insulting and provocative chiwiil-songs, full of sexual licence, to these women :

Namudim kabwaal kakujaal bwibwi.

Mother cultivator, your vagina is dirty

Yanng ku meem wakoowal kabwaal kakujaal bwibwi. Chibw kaandiing wiing oshiil and dark.

Go to the water to wash your vagina which is dirty and dark. Even the manioc root that you prepare (is dirty).

The song likens the polluted blackness of the female genitalia to the nocturnal descent into kaluung, while simultaneously linking the sexual and culinary universes. At the same time the novices' rebirth in the coming-out ritual has given them the authority of adult men. This newly acquired authority over women is further confirmed by the installation of a long pole, called mwiindal (in reference to the shrub in which Mukaanz installed his bird-trap), the following day. Such a pole, made of the mudidi-palm, is placed at all the paths that lead from the village to the bush. Every year, a similar, pole is erected at the start of the caterpillar harvesting period, in the beginning of February, on all the paths that lead to the bush. The village's elders thereby prohibit the women from starting to collect caterpillars before they are fully grown. The elders decide on which day the harvesting may start, and on that day, the pole is hauled down. At the end of the first day of the harvest, all the women of the village each present a basket of caterpillars to the elders. In doing so they acknowledge their gratitude for the fact that the elders lifted the prohibition. The elders will divide the received caterpillars among themselves. The erection 
of the pole thus symbolises the male control over economic use-values and female labour.

All the food which has been collected by the novices is carried to the zeemb. The billy-goat is cut into pieces by the mwiin mazeemb and the other elders, and divided into four portions. The owner of the goat is given the head. A second portion is for the teemb (the ones who performed the part of the $a v w$ $a$ nzaamb, another is for the guardians of the $s a k$, and one for the village head (mwaant wa $\mathrm{ul}$ ), in this case paramount chief Nzav, for " the zeemb belongs to him " (zeemb udi wa Nzav), since the political authority is also the main authority in the male sodality. It is Nzav who is esteemed to be the final holder of all the $n k a t^{17}$. The chicken that was killed is cut into little pieces and prepared by the initiation master's senior wife, together with some manioc mush. A ritual meal is shared on the zeemb by all the neophytes. This meal is refered to as -sumish luku ; " to cause to bite the manioc mush ». Every novice takes a bit of the chicken and the mush in his mouth and then spits it out. "To cause to bite the manioc mush » marks the end of a transitional ritual sequence with a transgressive character, such as the descent into the underworld in the case of the mwiingoony. It is because of the transgressive reversal that the vital order, the knotting of the three fields is creatively generated and brought about. The meal concludes the reintegration and renewal of the knotting of the corporeal, social and cosmological fields.

The rest of the day the neophytes are not allowed to leave the zeemb. In the afternoon the mwiin mazeemb collects all the plants that are worn by the atwaadi. These plants are tied to the luseel-pole. Subsequently, a piece of hair is shaved from the forehead of the atwaadi, which again marks a step in the gradual and potential acquiring of a new corporeal and social identity. The hair, together with the feathers, is tied into a bundle and buried later on by the mwiin mazeemb in a red ants' hole (mwizak-zak) in the bush. The novices' former selves are thus buried together with «their mother » Nansoomb. After

17. The initiation into the basic nkat at the end of the initiation ritual does not mean that one has come to know all the knots. Starting from his initiation into the mwiingoony, a man may choose to acquire on an individual basis other mwiingoony-nkat of a more esoteric and transgressive nature, such as the lukat lwa kaluung (the knot of the underworld), lukat lwa kajaam (the knot of the burial place), lukat lwa antaambw (the knot of the lions) and others. These may at the same time lead him into another initiatory cycle, the extremely secretive ampweepw, and into the elaborate and highly technical body of knowledge concerning sorcery (ulaj), for example concerning the ways to become invisible, to relocate oneself in space and time and so on. As such the mwiingoony, with its journey to kaluung, also inaugurates the human life-cycle as submitted to death and sorcerer's attacks, for " where the sorcerer says a word, the underworld listens" (mulaj waloond choom, kaluung witeesh).

Very few elders acquire full knowledge in all these domains. Nzav is considered to be the one in possession of all this secretive knowledge. Therefore, the basic sand-drawing (cf fig. 1) is often drawn with an encircling line, which represents a python (Python sebae). In the mukaand circumcision rituals the python occurs as a powerful metaphor for the transformation of female into male principles. As such the python symbolises both male virile identity, as represented in the authority of the elder, and maternal dedication. Indeed, female pythons are well-known for the way in which they encircle and hatch out their eggs, which they do not leave during a period of two to three months. The python's uluund name is kavuung a mpat, "the one who encircles the bush/land " (from the verb -vuung : to roll up, to coil, to encircle). In the same way as the python mother encircles her eggs, the paramount authority of Nzav assures the unity of the political territory (ngaand). Similarly, he is the locus, or the ultimate knot in which all secret knowledge comes together and in which male and female principles are most fully mediated on an institutional level. 
the shaving, the neophytes gather at the choot, where the initiated elders explain the basic sand-drawings to them. Before doing so, all the wives and female relatives of the atwaadi come " to raise what was bent down " (-djiindjul). By depositing a small gift in a basket on the choot in front of the neophytes who sit waiting with averted eyes, the women enable the atwaadi to raise their head and to look them in the eyes. It marks their return from death and their renewed relationship with the members of their domestic household unit.

After the kudjiindjul-ritual, the elders who were responsible for the ritual formally address the gathering, after which all the participants share a meal on the zeemb, consisting of the meat of the killed billy-goat and manioc mush, of which every woman of the village prepared a part on her own fire. The meal thus not only consolidates the bond of solidarity or " communitas » between the newly initiated members of the sodality, but also undescores the proper relationship between men and women. Thereafter the participants join their homesteads.

In the evening the participants again gather at the zeemb. After the swearing of an oath (cf note 8), the ritual passwords for entering the sak and the teemb are learned by the atwaadi, as well as the haanzam questions which every kadiaangw has to know by heart. Finally, every participant receives an initiationname from his guardian, which may only be mentioned in the context of the ritual and in the company of initiated men. For the last time, all the participants perform the mwiingoony-dances around the drummers. At the central pole (luseel lwi zeemb), the initiation master blows some kaolin (-pal mpeemb; -fuzil mpeemb) over the heads of the participants by way of blessing. This small name-giving ceremony marks the final conclusion of the process of gestation (initiation) and rebirth (coming out ritual at the river).

It appears from the internal process of sequential succession that the mwiingoony ritual event primarily unfolds on the level of the body-self. The initiation of the novices takes place in terms of impregnation, gestation and (re)birth. The novices' acquisition of a male body-self takes place by means of an inversion/regression into a female space-time where the origin of adult manhood is situated. The spatio-temporal ritual reversal which is performed in the mwiingoony enacts in an original way a common initiatory movement (Mary 1989). The transgressive return into the womb-like space-time of the zeemb, implies an encroachment and subversion of female bodily boundaries and orifices, which paradoxically establishes a new vital order. The rebirth on the corporeal level, achieved through a disruptive inversion, is congruent with a revitalization and integration of the generative processes and relationships that lie at the origin of the social and political body. The corporeal birth is paralleled by a social birth into distinctive manhood. Both spring from and are mediated by feminine cyclical regenerative processes, which are underscored by the maternal role of the mwiin mazeemb. The way in which the ritual performance unfolds stresses the importance of these mediating feminine powers and links them to macrocosmic processes. Corporeal and societal regeneration and renewal is performed by means of an enacted cosmogony, which links bodily and social processes to a more encompassing generation on the cosmological level. This in 
turn is evoked by the linkage between the spatio-temporal axes (east/west, $\mathrm{day} /$ night, upstream/downstream, sun/moon), the zeemb as female womb, gourd, house and ant's nest, impregnated by means of the masculine mupooltree, the mediation between white and red, axe and hoe, male and female principles. The macrocosmic metaphors for the regeneration of life display the contrasting and yet complementary nature of these polarities, and underline male and female interdependence in the cycle of life-transmission.

\section{THE CHIWIIL RITUAL}

Nansoomb walaalaang mwi shiind, walaangal weelik leel, namushaang iing amwaadil yikaang, namushaang amwas ditut dia wanga.

Nansoomb sleeps in the grass, she sleeps, what has she done today ? I left her when she spread the raffia mat, I left her and they have thrown the arrow of sorcery at her.

\section{Sequence 1. Initial preparatory phase}

The initiation master or mwiin kabaanz of the chiwiil is equally referred to as Nansoomb (or Nansool) and Nambaanz a Chiwiil. She has to be a senior woman, married to or agnatically related to the responsible elder of the village's longest established lineage (such as the Lukoonkesh, the most important female title at the royal court of Nzav), and to be in possession of the chiwiil's ritual basket (kaampaay) which is inherited matrilineally from one generation to the next. As with the mwiingoony, a formal demand " to lift up what is bent down " is made by one of the novices to the initiation master or mwiin kabaanz in front of the latter's house. The novice crawls on her knees towards the mwiin kabaanz and gives her a chicken while saying (Nansoomb, grandmother, I come to be initiated " (Nansoomb ngaak, neez nikit).

Very early the following day the mwiin kabaanz goes to prepare the initiation grounds (kabaanz), together with her husband. As with the mwiingoony the initiation grounds are situated to the east of the village. The woman with a hoe, the man with a machete, lay out the ritual path (mukuunk) which runs from west to east. The western starting point of the path is referred to as mwizak-zak, the hole of the red ants. The path leads in eastern direction towards two tress of chinkuunk (see the tale of the origin of the mwiingoony) that stand alongside one another and around which a site is cleared. This ritual ground is refered to as katoot. The space in the east at the back of the trees is called mwizaal. The path is laid out in between the two tress to find its end on the zaal, where the novices are made " to tremble " $(-z a a l)$. When clearing the site the initiation master (mwiin kabaanz) sings the song of the mukook, the female pendant of the kach a mukuund in the mwiingoony : "Eeey, people of makook (esoteric name for the chiwiil), people of kayaand, you must gather around me. Ah, the screams of chiwiil ! » During the actual initiation, two initiated women (atunyaam-nyaam) will sit behind each of the tress. One (to the lef) 


\begin{tabular}{|c|c|c|c|}
\hline \multicolumn{4}{|c|}{ Index of sequences in the chiwiil-ritual } \\
\hline sequences & $\begin{array}{l}\text { dramatis } \\
\text { personae }\end{array}$ & place & time \\
\hline $\begin{array}{l}\text { 1. preparation of } \\
\text { the kabaanz }\end{array}$ & $\begin{array}{l}\text { mwiin kabaanz }+ \\
\text { husband } \\
\text { - atunyaam-nyaam } \\
+ \text { novices }\end{array}$ & $\begin{array}{l}\text { kabaanz } \\
\text { choot (public } \\
\text { meeting place) }\end{array}$ & $\begin{array}{l}\text { morning } \\
\text { noon }\end{array}$ \\
\hline $\begin{array}{l}\text { 2. kukitish } \\
\text { - learning of the } \\
\text { nkat (kaampaay } \\
+ \text { nsup ya } \\
\text { ndjuumb) }+ \\
\text { communal meal }\end{array}$ & $\begin{array}{l}\text { mwiin kabaanz }+ \\
\text { atunyaam-nyaam } \\
+ \text { novices } \\
\text { - mufw } \\
\text { - nlaandmin } \\
\text { - mujiing } \\
\text { - nakapeesh }\end{array}$ & $\begin{array}{l}\text { village (shared } \\
\text { house) }\end{array}$ & afternoon \\
\hline $\begin{array}{l}\text { 3. the descent to } \\
\text { the stream + } \\
\text { bath }+ \\
\text { appearance of } \\
\text { nkat }\end{array}$ & $\begin{array}{l}\text { mwiin kabaanz }+ \\
\text { atunyaam-nyaam } \\
+ \text { novices } \\
\text { - nlaandmin } \\
\text { - faan } \\
\text { - namusaal } \\
\text { - nakatoong } \\
\text { - nankuunkol } \\
\text { - kayaand }\end{array}$ & stream & morning \\
\hline $\begin{array}{l}\text { 4. kukwaat nkay } \\
\text { the catching of } \\
\text { the bushbuck } \\
\text { - kudjiindjul }\end{array}$ & $\begin{array}{l}\text { - mwiin kabaanz } \\
\text { etc. } \\
\text { - nkay (member } \\
\text { of mwiingoony } \\
\text { sodality) }\end{array}$ & village & $\begin{array}{l}\text { morning } \\
\text { afternoon }\end{array}$ \\
\hline
\end{tabular}

will represent the lukat Mujiing, the daughter of Nansoomb. The other (to the right) will represent the lukat Nakapeesh, " the mother with the pipe », or the female elder. On the path (mukuunk) that leads to the initiatory grounds three ritual barriers (nkiindji, from the verb-kiindjik : « to block off », " to close ») are erected ${ }^{18}$. In front of the chikuunk-tress, she places the ritual basket (kaampaay) to the right (when one faces west) on a low stool (mukaangu), and

18. As in the mwiingoony each village has its own way of constructing the gateways to the initiation grounds. Most often these barriers consist of the plant malat (Zingiberacea, Costus spectabilis) which is laid on both sides of the path and on which is deposited a leaf of the plants mutuungul and mukuundikil (cf mwiingoony). Then the initiation master puts a green branch of the tree muwudi across the path. 
a small gourd, the so-called " gourd of the sister » (nsup ya ndjuumb) on another stool to the left, together with a piece of termite's nest, referred to as " grandmother » (ngaak), also called Kaaj or Nambaanz a chiwiil. The names again refer to the qualities of the archetypal mother figure of Nansoomb, whereas the termite's nest also refers to female fecundity.

The ritual basket is smeared with red earth (mukuundju). It contains a number of human, animal and vegetable ritual substances (nkaw), among which is " rainbow » (nkoongol), as well as some miniature statues, the number of which may vary from three to nearly twenty. The most important statues are nlaandmin, the " dominated » dead (cf sequence of the mwiingoony), nankuunkol (the chiwiil-name for the stilt-walker muyiind and a reference to Nansoomb) and kayaand (a reference to the mwiingoony oath which is of feminine origin) ${ }^{19}$. An arrow, referred to as « the sister of chiwiil» (ndjuumb a chiwiil), is stuck in the middle of the basket. The arrow is a reference to the arrow with which Nansoomb was killed by her husband ${ }^{20}$. The small " gourd of the sister » is dotted with kaolin and red earth and contains most of the same ritual substances as the basket, including the "rainbow ", and "lightning " (nzaj).

After the preparation of the initiation grounds, the female initiation master will collect manioc roots and palmwine from every novice. These will be consumed during the initiation.

\section{Sequence 2. The initiation (-kitish)}

At noon, the mwiin kabaanz returns to the village and, with a machete in her hand, goes to the public metting place (choot), where all the novices gather around the initiation master who is singing and performing chiwiil-dances.

18. (suite) Both ends of the branch rest on the malat on the two sides of the path. In other versions a knot is tied in a tuft of kaswaam grass (jiind) at both sides of the path. According to some informants these tufts are referred to as muchiaal and kalwiimb, a reference to the village of Chiaal and the river Kalwiinsiku. In the middle of the path, in between the two tufts, the initiation master deposits two sticks of the trees muwudi and mukul. They form the door to the initiation ground. Only initiated persons will know how to open this door in the proper way and with the proper ritual formulae. 19. Other statues may include nakatoong, " the spotted mother "; ann ampaamb, " the twins "; neeng, « the plaintive woman. (Neeng is also the name of a small glossy yellow starling, one of the birds that was captured in the bird-traps of Mukaanz. Some informants said it was the name of one of the first chiwiil initiation masters) ; nakapeesh, "the pipe-smoking mother ", kukeep kwa nguy, " the little needle "; namusaal, " the mother of the basketry sieve "; muyiind, the stilt-walker ; muteen waansas mwaang a maleelu, "the sun that shines makes the clouds disappear in the sky ", a reference to the chiwiil ritual which makes ininitiated people flee like the clouds flee for the sun; kaful, Turtle : in the chiwiil it is sung how Turtle went to steal maize and groundnuts in the villages. As such, it represents the stilt-walker ; kanam, the name of one of the mwaant yaav's senior daughters, and the name given to the lineage's most senior woman ; and others.

To the left side of the basket is stuck a feather of the helmeted guinea hen nkaang (Numidia meleagris). To the right is attached a feather of the tauraco ndjuw (Musophaga rossae). Both feathers are invariably used in ritual contexts with a transgressive character, implying the flowing of blood and killing. To both sides of the basket is hung a mbaansh fruit (cf mwiingoony).

20. The ndjuumb a chiwiil is equally a lukat or "knot " of knowledge of the chiwiil. It consists of a piece of wood (lubaanz) of the mudidi-palm, which is dotted with kaolin and red earth, and at which is attached a long string, by means of which the wood is swung around in the air. The wood's swift movement produces a loud humming sound, said to be the lamenting voice of the deceased. The ndjuumb a chiwiil is swung both during chiwiil-rituals and during the mourning following upon the death of a member of the chiwiil-sodality. 
As in the mwiingoony, each of the girls will be accompanied by a guardian (chikolkol), an adult initiated woman, who will take care of her novice or « child of chiwiil " (mwaan a chiwiil) during the initiation. All the initiated women (atunyaam-nyaam) wear the masas ritual dress in maniingan fashion : a number of cloths which are wrapped around the hips and in which leaves of the mutuungul and the mukuundikil are stuck. Both atunyaam-nyaam and novices are bare-breasted and their bodies are smeared with circles of kaolin and red earth. Each of the novices will present a small sum of money, referred to as chikaang or mukos, to the mwiin kabaanz. Chikaang is the name given to a woven raffia mat. Such mats are made by men and only used by important elders. Formerly, the novices' husbands or male relatives presented a chikaang to the mwiin kabaanz. The mats were used for the novices to sit upon during their stay on the initiation grounds. The sitting on the chikaang mats indicates the reversal of values that characterises ritual behaviour on the initiatory grounds (kabaanz). In the same way as the master of the zeemb and the male guardians in the mwiingoony acted as mothers to the novices, so the master of the kabaanz and the guardians of the " children of chiwil " adopt the attitude of the male elder (cf for example the lukat Nakapeesh).

All the novices leave the village for the initiation ground, in silence and with their heads turned down. The procession is headed by the mwiin kabaanz and accompanied by the other initiated women, who will sing chiwiil songs. When the procession arrives at the ritual path, the novices proceed crawling on all fours $(-k u l u b)$ until they reach the first barrier. There an initiated woman is stretched out across the path, covered by a piece of cloth, under which other cloths have been put. She represents the lukat nlaandmin ( $\mathrm{cf}$ mwiingoony), the swollen and putrefied corpse of a dead person, full of maggots (aminfuny) that feed on the corpse's flesh. At the second barrier lays another woman in similar fashion, representing the lukat mufw, "the dead person ». While one of the initiated women is swinging the ndjuumb a chiwiil (see note 21) and all the guardians are singing chiwiil-songs, each of the novices crawls over the " dead person », without touching it. Each time the initiation master informs the novice of the name of the lukat and asks her to repeat it. Thereupon she invites the novice "to enter" (-aandam).

The third barrier forms the entrance to the place where the basket is exposed. Before entering, each novice is made "to drink " from " the gourd of the sister ». Sitting on her knees, the novice cringes and crawls to the gourd, which she lifts with her teeth, while the initiated women sing :

mukish wa ndjuumb The mask of chiwiil ( = the gourd)

mukal kubwaak

It is hard to get initiated

wabwaak ndjuumb

wabwaak chiwiil

If you are initiated in the sister (if you have «drunk » from the gourd) you are initiated in chiwiil.

After " drinking " from the gourd the novice then crawls to the cleared site behind the two chinkuunk-trees (mwizaal) and sits down behind the two women who represent Mujiing and Nakapeesh. When everyone has arrived on the site, one of the guardians will light a fire, and the initiation master will 
offer a chicken to the novices. The chicken is roasted (nzool wa whibababaab) and eaten with some manioc mush by all those present. By sharing a communal meal the special relationship that exists between the novices of the same chiwiil performance is accentuated.

The drinking from the gourd initiates the novices into the regenerative and nurturing powers that characterize womanhood, for it is the gourd/womb (together with the heart) which constitutes the main corporeal locus of the female body-self and its life-transmitting capacities. At the same time, the initiation takes place in a predominantly male time space. Actually, the chiwiil-ritual unfolds as a sequential reversal of the mwiingoony. The male initiation constituted a spatial and temporal movement from day to night, from east to west, from life to death, from upstream to downstream, from a male into a womblike, female, nocturnal time space. It is within this female space that the novices are "processed » and initiated to full adult manhood. The chiwiil ritual, on the other hand, takes place during the daytime (although the novices' songs compare the " hardships » of the initiation to the blackness of the night). Spatially, it predominantly unfolds according to a west/east axis. Whereas the male novices performed the descent into the underworld and only crawled over the anlaandimin at the end of the ritual initiation, thereby enacting their rebirth and their domination of death, the chiwiil starts with a movement out of the underworld. The western edge of the ritual path is referred to as the red ants' nest (mwizak-zak), the burial-place of Nansoomb and source of female fecundity. The initiates come crawling out of the ants' hole and over the nlaandmin in the beginning of the ritual. Whereas the male novices performed an inversion or regression into the female origins of the process of life-transmission, the female novices enact an inversed and equally transgressive journey towards the male source of individual life as well as Luunda culture and political institutions that were brought by paramount chief Nzav from the eastern kool or Luunda heartland. The novices' journey unfolds sequentially in a movement from night to day, from west to east, from moon to sun, from downstream to upstream. According to my informants the ritual path which leads to the chinkuunk-trees is the river lweemb (cf fig. 1) which the novices follow in upstream direction. As the mwiingoony novices discovered their true male bodyselves in the center of the female womb, so the female atwaadi are made conscious of and invested with feminine regenerative powers at the core of male time space, being the upstream source from which the male world springs and which is symbolised by the phallic chinkuunk-trees. It is through their " upstream » journey, through the drinking of the "lightning » and the " rainbow " that were contained in the gourd, and through their entrance to the zaal by slipping in between the two phallic chinkuunk-trees that the novices' bodies are symbolically penetrated and impregnated by the male, linear and cumulative flow of seminal waters. The ritual journey and symbolic impregnation reveals to the novices their true nature as maternal containers of raw masculine lifeprinciples. The initiation thus completes their corporeal metamorphosis. It turns their inherent feminine fecundity, acquired in the menarche rituals of ufuundeej, into bodies of motherhood, symbolised by the gourd and the basket. It is there, on the zaal, that they will be initiated into the corpus of secret knots 


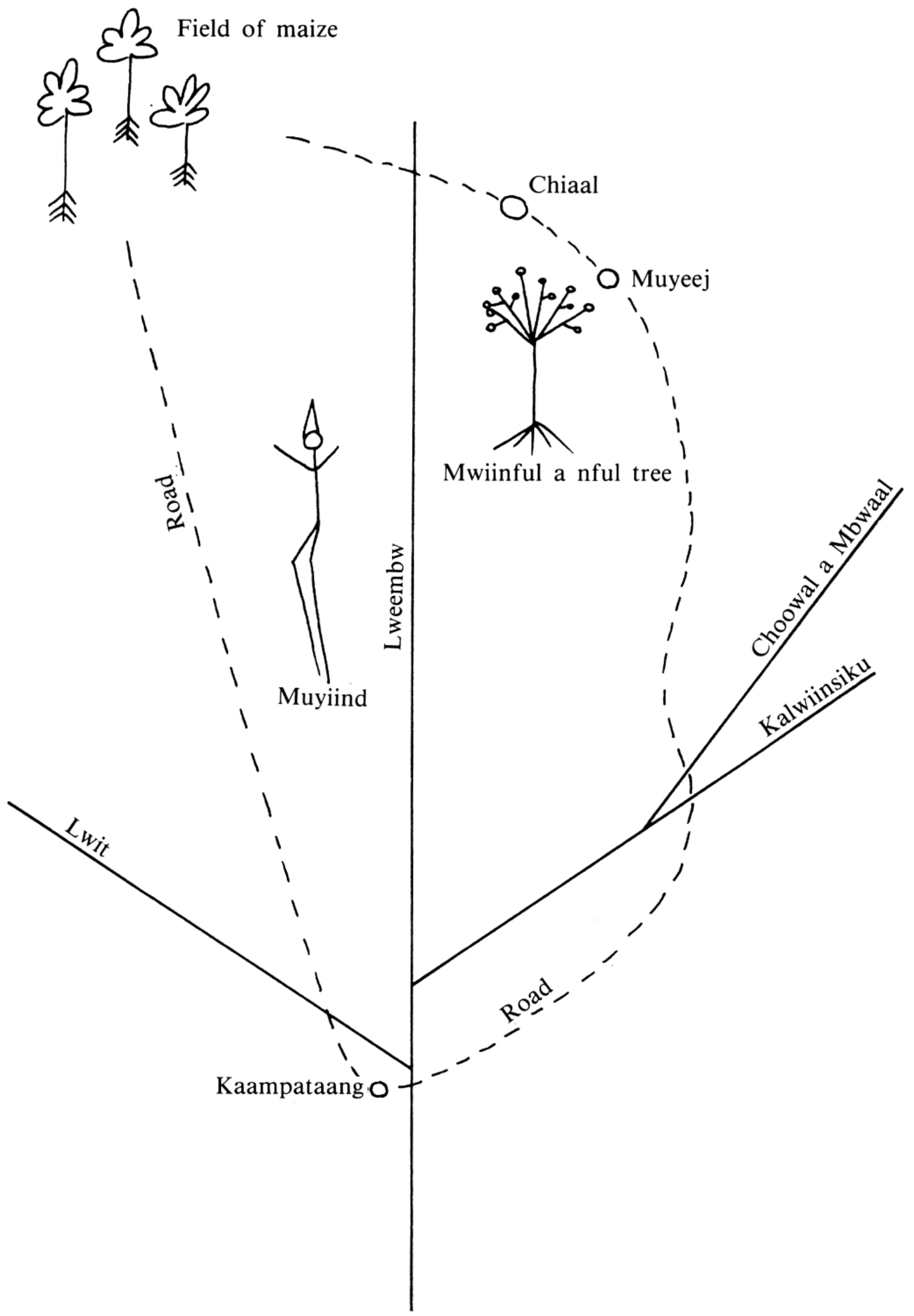

Figure 1 
that constitutes feminine esoteric knowledge. After the arrival of all the novices on the zaal, the initiation master and the guardians teach them the initiatory songs and dances that celebrate these feminine powers, which are primarily conveyed on a corporeal level (for example in the danced performance of the "showing " of the female genitalia). They also reveal to the novices the proper passwords for entering the initiation grounds, as well as the composition of the ritual basket and the way the ritual substances and statues are " hammered » or « driven into the basket » (-paamp kaampaay) ${ }^{21}$. One of the songs that are sung by the initiated women during the " hammering " of the basket, clearly reveals the newly acquired feminine powers of gestation and regeneration, and also links the corporeal, sexual and nutritional domains : " Big sister Nansool has given me the skin of the vagina. How shall I eat it, roasted or cooked ? " (yaay Nansool akaniink chikit cha mbwaal, nichidi chakoosh aang chikwiisik ?) These initiatory songs are full of sexual license and, as in the case of the songs sung after the clubbing of the billy-goat, they imply a ritual reversal of normal norms of politeness.

It is only correct that this knowledge is conveyed to them at the zaal, the ritual time-space which symbolically refers to the upstream source of the masculine vital life-flow and institutionalised authority, for the nkat of chiwiil were given to the women by the men. As such, chiwiil is also the institutionalised recognition of the male model of gender relations, which confines and limits the corporeal and social scope of women's roles as mothers and cultivators to that of the basket. At the same time the ritual asserts the contrasting but complementary female interaction model. The communal meal, for example, forms an illustration of feminine nutritive power and self-sufficiency. Furthermore, the initiation into chiwiil does not only define female body-self and social body by investing the novices with feminine regenerative and nurturing powers and by turning their bodies into the bodies of motherhood, but it also confirms the dependence of men on these female qualities. In the chiwiil it is conveyed to the novices that women used to detain the elements on which male authority builds. Significantly, the basket and gourd contain ritual substances that derive from lightning (nzaj) and the rainbow (nkoongol), two of the most powerfully cosmic symbols of masculine erectness, verticality, coercive authority and control. A famous Luunda tale, in which Lightning and his son Rainbow kill their wife and mother, the two-headed aquatic serpent Chyaanz a Ngoomb, fully illustrates the masculine coercive dimensions of the rainbow and of lightning, and expand on a cosmic level the theme of the mother-murder that underlies the basic core of nkat of both the mwiingoony and chiwiil rituals.

In the evening the novices and their guardians return to the village, where they will spent the night together in one house. During the night they will also share another communal meal, prepared by the guardians. The only persons who may visit the novices in the communal house at night are their parents-in-law (ayiwaaj). Again, this reverses the normal relational roles proper to every Muluund,

21. Prior to this, each of the novices offers a small sum of money, the socalled chiloongil or " learning ", to the initiation master. This gift allows her to reveal the chiwiil's secrets. Afterwards the atwaadi novices present her with another gift, the chituumweeshin, " the gift that causes to stand upright ". This gift allows the novices to leave the chikaang mat on which they were seated. 
for normally ayiwaaj will avoid one another. As in the mwiingoony, the reversal of roles on the social level, mirrors the ritual reversal on the corporeal and cosmological levels that was achieved in and through the transgressive ritual journey upstream. Similarly, the preparing of a meal during the night reverses, disrupts and confuses the normal order of Luunda time-space relations, by mixing up the vital boundaries between night and day and the activities that are proper to them.

\section{Sequence 3. The descent to the stream}

At the first crowing of the cock, everyone moves back to the initiation grounds where dawn is awaited. From there all the novices are led to the stream. As in the mwiingoony, they first have to step over a nlaandmin, for the journey to the stream is a return to the underworld in the context of the chiwill : it is there that the final nkat of the chiwiil will be revealed to them. They enter the water, together with their guardians, and sit down in the middle of the stream, their faces turned upstream. With the return to the world of death from which they came, the processual development of the ritual event unfolds as a structural illustration of female cyclical principles.

As with the appearance of the muyiind, kaleew-leew and kaminyoongw on the zeemb, there will now appear some nkat of chiwiil, performed by initiated women (atunyaam-nyaam) who wade through the water in downstream direction towards the novices.

- Faan : at her appearance the guardians and the novices start singing a song dedicated to this lukat. The name of the lukat literally means « resemblance ». The woman is smeared with ashes (mishit) all over her face and resembles the night, death and the world of sorcery.

- Namusaal : " the mother of the basketry sieve ». Like the gourd, the basketry-sieve with which manioc flour is sifted, is another metaphor for the maternal container of the womb. The term musaal recurs in other contexts. The musaal is a ritual fence in a woman's seclusion hut (maseeku) where she gives birth after being attained by a spiritual agency (haamb). The musaal denotes the sheltered and womb-like quality of the seclusion in the hut. Finally, the musaal-tree (Caesalpiniaceae, Dialium englerianum) is called « the tree of the mothers" (mutoond wa amaakw). The tree occupies a central position in the menarche rituals of ufuundeej. As such it signifies female fecundity, and its leaves and roots are used as basic substances in the preparation of «medicine for engendering " (moon ya kusem). The namusaal approaches the girls and women who are seated in the water. In front of them she plunges the basketry sieve she holds in her hands into the water and pulls it up again, making sifting movements. While the water pours out of the sieve, the namusaal starts a song: "Mother, the gourd, the gourd is broken."

- Nakatoong : " the spotted mother ». This lukat is performed by a woman who is smeared with circles of kaolin and red earth over her whole body. As most of the other nkat, the nakatoong has her own song.

- Nankuunkol : the chiwiil name for the muyiind stilt-walker, originally invented by Nansoomb. The stilt-walker who appears wears very short stilts and moves as if she were badly wounded. 
- Kayaand : the last lukat to appear is kayaand ni nsal jeend, "Kayaand with her feather hat ", a woman with a feather hat drawn on her belly with kaolin and red earth, and wearing a real nsal feather hat, made from the feathers of the births that Mukaanz trapped in his birdtraps at the chinkuunk or mwiinful a nful trees. Using the esoteric language from the mwiingoony the Kayaand sings the enigmatic song : " $\mathrm{O}$ the duiker burned its arse because it prepared manioc mush. Child of Mujiing and Kaluumb, gather around me on the zaal $^{22}$. ")

As the stepping across the nlaandmin and the appearance of faan indicates, the whole sequence enacts a return to death and to the red ants' nest, the burial place of Nansoomb. The nkat perform the women's grief over the death of the mythical mother-figure Nansoomb, and over the male appropriation and thus female loss of control over regenerative and nurturing powers by the women due to this murder. This loss is symbolised by the broken " gourd »/sift, which my informants said stands for the maternal womb of Nansoomb, the mother of all the chiwiil members. The significance of the nakatong-figure remains obscure to me. The most important figure certainly is kayaand. Again, the origin of male authority and control, summarised in the swear-word kayaand (cf note 6 ) and in the feather hat, is clearly traced back to its female origins, as the nsal drawing on the woman's belly, and her use of the mwiingoony's esoteric language in the kayaand-song makes abundantly clear. At the same time the kayaand's song affirms that the initiation into the chiwiil implies a growth towards a new social identity as mother, cultivator and cook, for it is the " duikers "), the men, the antoond, those who remain uninitiated, who burn their behinds in trying to cook and prepare food. In other words, men, or uninitiated women, are uncapable of performing the role of an adult woman and mother.

After the appearance of the nkat and the purifying bath which indicates the end of the mourning over Nansoomb/kayaand, the novices warm themselves at a fire in the bush. There, the guardians will shave a tuft of hair from the heads of their novices, and the novice's bodies will be painted with specific figures and signs that are part of the chiwiil's body of secret language (in the same way as the sand-drawings for the mwiingoony). The paintings are representations of most of the nkat that appeared during the ritual event, but also include representations of the rainbow and the centipede (choongol). Both the shaving and the body-painting mark on a corporeal level the novices' change from " bushbucks » to mothers and fully adult members of the Luunda community, in their newly acquired maternal role. Through their initiation, they themselves have become Nansoomb. After adorning their bodies the novices share a last communal meal, mirroring the "biting of the mush » meal in the mwiingoony. It is after this meal that they will receive an initiation name from their guardians in a similar fashion as in the mwiingoony.

22. Depending on the local chiwiil traditions other nkat may appear as well. Owing to shortage of space I merely give a short description of the most frequent ones.

The duiker mentioned in the song of the kayaand is the white- or yellow-backed duiker called chiinkum, kum or mbiind (Cephalophus Sylvicultor), which shares the masculine connotations of the nkay duiker. 


\section{Sequence 4. Kukwaat nkay: the capturing of the bush-land duiker}

This last sequence mirrors the mwiingoony's clubbing of the billy-goat and the collective killing of the chicken. A man, initiated member of the mwiingoony, hides in the bush ${ }^{23}$. Around his belt he carries the hide of the small duiker nkay (Sylvicapra grimmia). The initiation master orders the novices " to grab » the duiker (-kwaat nkay) and starts singing the song boolaany ankay, " let us search for the duikers " (-bool : " to break a path ", " to search »). When the novices finally get hold of the " duiker ", they enact the hunter's movements of slaughtering, skinning and cutting up the animal.

The significance of the sequence mirrors the men's achievement of their masculine body-self and their acquisition of and victory over feminine powers in the mwiingoony. The novices here take on the masculine and virile role of the hunter. As the killing of the chicken enacted the killing of Nansoomb, the killing of the duiker is the performance of the victory over male-inflicted death, and thus over male authority and control, represented in the basic ritual tale by the hunter and husband Mukaanz, and his murdering of Nansoomb. The symbolic butchering of the duiker expresses and celebrates the acquisition of the male powers, symbolised by the nkay. Both Turner (1968) and Rodrigues de Areia (1985 : 329) remark upon the nkay's connotations of virility and masculine fecundity among the Ndembu and the neighbouring Cokwe. The sequence of the capturing of the nkay-duiker thus fully asserts the female gender model (through the killing of the nkay and the appropriation of its " masculine " qualities). At the same time it asserts once more the complementarity between male and female models, for it is only through the completion of masculine powers that full womanhood is achieved.

When all the participants return to the village, they gather at the choot to perform a final chiwiil dance, on the rhythm of the men's drums, thus publicly establishing the fact that they have been initiated and own the right to swear chiwiil. One by one the men fetch their wives or relatives by performing the act of kudjiindjul. The man holds a small sum of money against the woman's forehead and pushes it up, so that their eyes meet and the woman is " brought back " from her transgressive journey. The men will then give the money to the initiation master, together with a chicken and a gourd of palmwine. These goods will be divised among the guardians of the novices.

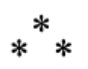

This paper aimed at an analysis of the twofold intentionality of the mwiingoony and chiwiil initiatory rituals as the realisation of the dual and asymmetrical complementarity that underpins the crucial organisational principles of Luunda society at large. I have attempted to show how the sequential development of the ritual, by means of a performative production of the distinctive male and female body-self, also replenishes, generates and creatively esta- 
blishes the interdependence between two alternative gender models, which in turn were reflected upon a broader socio-political field, as well as the Aluund's worldview. The transformative ritual process, marked by its paradoxical transgressive and disruptive character, is therefore to be understood as an attempt to " knot " the corporeal, social and cosmological fields into one meaningful and integrated whole, thereby consolidating the " fertility » and vital order, the maintainance and perpetuation of Luunda society.

\section{Leuven, Center for Social and Cultural Anthropology}

\section{BIBLIOGRAPHIE}

BASTIN, M.L. 1984. « Mungonge : initiation masculine des adultes chez les Tshokwe (Angola) », Baessler Archiv, Neue Folge, 32 : 361-89.

Bellman, B.L. 1984. The Language of Secrecy. Symbols and Metaphors in Poro Ritual. New Brunswick, Rutgers University Press.

BLOCH, M. 1982. "Death, women and power ", in Bloch, M. \& J. Parry (eds), Death and the Regeneration of Life. Cambridge, Cambridge University Press, 211-30.

BLOCH, M. \& J. PARRY, 1982. "Introduction", in Death and the Regeneration of Life. Cambridge, Cambridge University Press : 1-44.

BOURDieU, P. 1980. Le sens pratique. Paris, Minuit.

CRINE-MAVAR, B. 1963. "Un aspect du symbolisme Luunda. L'association funéraire des Acusyaang ", Miscellanea Ethnographica (Tervuren) : 79-108.

DE HEUSCH, L. 1972. Le roi ivre ou l'origine de l'État. Paris, Gallimard.

DE SOUSBERGHE, L. 1956. Les danses rituelles mungonge et kela des Ba-Pende (Congo belge). Bruxelles, Académie royale des sciences coloniales.

DEVISCH, R. 1984. Se recréer femme. Manipulation sémantique d'une situation d'infécondité chez les Yaka du Zaïre. Berlin, Dietrich Reimer Verlag.

- 1988. - From Equal to Better : Investing the chief among the northern Yaka of Zaïre ", Africa 58 (3) : 261-90.

ELIADE, M. 1952. "Le " Dieu Lieur" et le symbolisme des nœuds ", in Images et symboles. Essais sur le symbolisme magico-religieux. Paris, Gallimard : 120-63.

FERNANDEZ, J.W. 1982. Bwiti. An Ethnography of the Religious Imagination in Africa. Princeton, Princeton University Press.

GILGES, W. 1955. Some African Poison Plants and Medicines of Northern Rhodesia. Lusaka, Rhodes-Livingstone Institute.

HOLY, L. 1985. "Fire, Meat and Children : the Berti myth, Male Dominance and Female Powers ", in Overing, J. (ed), Reason and Morality. London/New York, Tavistock.

HOOVER, J.J. 1978. " Mythe et remous historique: A Lunda Response to de Heusch », History in Africa, $5: 63-80$.

LÉVI-STRAUSS, C. 1971. Les structures élémentaires de la parenté. Paris, Mouton. MARY, A. 1989. « Le schème de la naissance à l'envers : scénario initiatique et logique de l'inversion », Cahiers d'études africaines, 28 (2) : 233-63.

NANGE KUDITA WA SESEMBA. 1981. L'homme et la femme dans la société et la culture Cokwe. Louvain, Université catholique de Louvain (Unpublished doctoral dissertation). 
PLANQUAERT, M. 1930. Les sociétés secrètes chez les Bayaka. Louvain, Kuyl-Otto. RODRIGUES DE AREIA, M.L. 1985. Les symboles divinatoires. Analyse socio-culturelle d'une technique de divination des Cokwe de l'Angola. Coimbra, Instituto de Antropologia.

TAMBIAH, S.J. 1985. "A Performative Approach to Ritual ", in Culture, Thought and Social Action. An Anthropological Perspective. Cambridge, Mass./London, Harvard University Press : 123-66.

TURner, V.W. 1968. The Drums of Affliction : A Study of Religious Process among the Ndembu of Zambia. Oxford, Clarendon Press.

WerbNer, R.P. 1989. Ritual Passage Sacred Journay. The Process and Organization of Religious Movement. Washington/Manchester, Smithsonian Institution Press/Manchester University Press.

ZEMPLÉNI, A. 1976. " La chaîne du secret ", Nouvelle Revue de psychanalyse, 14 : 313-24.

\author{
ON BUSHBUCKS WITHOUT HORNS : \\ MALE AND FEMALE AMONG THE ALUUND OF SOUTHWEST ZAÏRE \\ FILIP DE BOECK
}

\begin{abstract}
Among the Aluund of southwestern Zaïre, the mwiingoony is open to all circumcised men ; and the chiwiil, to all women who have undergone menarche rites. To initiate men and women into these "sodalities " means transforming them from " bushbucks without horns " (the uninitiated) into knowledgeable initiates so that they acquire a practical awareness of their distinct, yet interdependent, male and female body-selves, of the alternative models of Luunda gender relations, and of the social responsibilities of manhood and womanhood. Light is shed on these creative, transformative initiatory practices; and rites are analyzed sequentially as a processual bodily action and a generative process of meaning production.
\end{abstract}

\title{
GUIBS SANS CORNE : MASCULIN ET FÉMININ PARMI LES ALUUND DU SUD-OUEST DU ZAÏRE FILIP DE BOECK
}

Parmi les Aluund du sud-ouest du Zaïre, le mwiingoony est ouvert à tous les hommes circoncis comme le chiwiil l'est à toutes les femmes ayant subi les rites de ménarche. Quand ils sont initiés dans ces sociétés, les hommes et les femmes sont transformés de "guibs sans cornes " (de non-initiés) pour devenir des initiés ayant acquis des connaissances du corps en tant qu'ensemble de rapports, distincts mais interdépendants, entre le féminin et le masculin. Ils apprennent les modèles des rapports entre les genres parmi les Luunda, et deviennent conscients des responsabilités sociales qu'impliquent la masculinité et la féminité. Les séquences de ces rites sont soumises à une analyse qui les saisit à la fois comme une action corporelle et un processus qui génère un sens pour la production. 